\title{
Effects of calcium level and source, formic acid, and phytase on phytate degradation and the microbiota in the digestive tract of broiler chickens
}

Jochen Krieg ${ }^{1 \dagger}$, Daniel Borda-Molina ${ }^{1 \dagger}$, Wolfgang Siegert $^{1 *} \mathbb{D}$, Vera Sommerfeld ${ }^{1}$, Yung Ping Chi ${ }^{1}$, Hamid Reza Taheri ${ }^{1,2}$, Dieter Feuerstein ${ }^{3}$, Amélia Camarinha-Silva ${ }^{1}$ and Markus Rodehutscord ${ }^{1}$

\begin{abstract}
Background: Diet acidification, dietary calcium (Ca) level, and phytase supplementation are known influences on the microbial community in the digestive tract and on phosphorus $(\mathrm{P})$ utilization of broiler chickens. Effects of dietary factors and microbiota on $\mathrm{P}$ utilization may be linked because microorganisms produce enzymes that release $P$ from phytate $\left(\operatorname{InsP}_{6}\right)$, the main source of $\mathrm{P}$ in plant feedstuffs. This study aimed to detect linkages between microbiota and $\mathrm{InSP}_{6}$ degradation by acidifying diets (i.e., replacing $\mathrm{Ca}$ carbonate $\left(\mathrm{CaCO}_{3}\right)$ by $\mathrm{Ca}$ formate or adding formic acid to $\mathrm{CaCO}_{3}$-containing diets), varying $\mathrm{Ca}$ levels, and supplementing phytase in a three-factorial design. We investigated i) the microbial community and $\mathrm{pH}$ in the digestive tract, ii) prececal (pc) $\mathrm{P}$ and $\mathrm{Ca}$ digestibility, and iii) Ins $\mathrm{P}_{6}$ degradation.

Results: All factors under investigation influenced digesta $\mathrm{pH}$ and the microbiota composition. Predicted functionality and relative abundance of microorganisms indicated that diets influenced the potential contribution of the microbiota on InsP degradation. Values of $\mathrm{InsP}_{6}$ degradation and relative abundance of the strains Lactobacillus johnsonii and Lactobacillus reuteri were correlated. Phytase supplementation increased pc InsP 6 disappearance, with differences between Ca levels, and influenced concentrations of lower inositol phosphate isomers in the digestive tract. Formic acid supplementation increased $\mathrm{pc} \mathrm{InsP}_{6}$ degradation to myo-inositol. Replacing $\mathrm{CaCO}_{3}$ by Ca-formate and the high level of these $\mathrm{Ca}$ sources reduced $\mathrm{pc} \mathrm{InsP}_{6}$ disappearance, except when the combination of $\mathrm{CaCO}_{3}+$ formic acid was used. Supplementing phytase to $\mathrm{CaCO}_{3}+$ formic acid led to the highest Ins $\mathrm{P}_{6}$ disappearance (52\%) in the crop and increased myo-inositol concentration in the ileum digesta. Supplementing phytase leveled the effect of high Ca content on $\mathrm{pc}$ Ins $\mathrm{P}_{6}$ disappearance.

Conclusions: The results point towards a contribution of changing microbial community on $\operatorname{lns}_{6}$ degradation in the crop and up to the terminal ileum. This is indicated by relationships between InsP $\mathrm{P}_{6}$ degradation and relative abundance of phosphatase-producing strains. Functional predictions supported influences of microbiota on $\operatorname{Ins}_{6}$ degradation. The extent of such effects remains to be clarified. Ins $\mathrm{P}_{6}$ degradation may also be influenced by variation of $\mathrm{pH}$ caused by dietary concentration and solubility of the Ca in the feed.
\end{abstract}

Keywords: Calcium, Phytate, Microbiota, Functionality, Broiler chickens

\footnotetext{
* Correspondence: inst450@uni-hohenheim.de

${ }^{\dagger}$ Jochen Krieg and Daniel Borda-Molina contributed equally to this work. 'Institute of Animal Science, University of Hohenheim, 70599 Stuttgart,

Germany

Full list of author information is available at the end of the article
}

(c) The Author(s). 2021 Open Access This article is licensed under a Creative Commons Attribution 4.0 International License, which permits use, sharing, adaptation, distribution and reproduction in any medium or format, as long as you give appropriate credit to the original author(s) and the source, provide a link to the Creative Commons licence, and indicate if changes were made. The images or other third party material in this article are included in the article's Creative Commons licence, unless indicated otherwise in a credit line to the material. If material is not included in the article's Creative Commons licence and your intended use is not permitted by statutory regulation or exceeds the permitted use, you will need to obtain permission directly from the copyright holder. To view a copy of this licence, visit http://creativecommons.org/licenses/by/4.0/. 


\section{Background}

High utilization of phosphorus $(\mathbf{P})$ provided by plant feedstuffs is advantageous because less or no mineral $\mathrm{P}$ is needed to fulfill the $\mathrm{P}$ requirement of animals. Plant$\mathrm{P}$ is mainly bound in phytic acid [myo-inositol 1,2,3,4,5, 6-hexakis (dihydrogen phosphate); $\mathbf{I n s}_{\mathbf{6}}$ ] and present as phytate, which requires hydrolyzing enzymes to make $\mathrm{P}$ available for the animal. Hence, phytases are widely used as feed additives in non-ruminant nutrition. The main effect of phytases is the cleavage of $\mathrm{P}$ from Ins $\mathrm{P}_{6}$ to increase $\mathrm{P}$ utilization by animals. When diets are fed with the supplementation of mineral $\mathrm{P}$ and calcium (Ca), but without supplemented phytase, prececal (pc) Ins $_{6}$ degradation is reduced in broiler chickens [1]. The reduced degradation of $\operatorname{Ins}_{6}$ upon $\mathrm{Ca}$ supplementation is usually explained, among other reasons, by the formation of $\mathrm{Ca}-\mathrm{InsP}_{6}$ complexes in the digestive tract at high $\mathrm{Ca}$ concentrations $[2,3]$.

It was shown that bone mineralization of broiler chickens can differ as a result of varying $\mathrm{Ca}$ sources when supplied in equal $\mathrm{Ca}$ concentrations [4] and that using different $\mathrm{Ca}$ sources can have other consequences, such as impacts on the microbial community of the digestive tract of broiler chickens [5]. Studies investigating the impact of dietary $\mathrm{Ca}$ on $\mathrm{P}$ utilization usually used limestone as a $\mathrm{Ca}$ source, which mainly consists of calcium carbonate $\left(\mathrm{CaCO}_{3}\right)$, a compound with a high buffer and acidbinding capacity. Increasing $\mathrm{pH}$ in the digestive tract supports formation of $\mathrm{Ca}^{-\mathrm{InsP}_{6}}$ complexes and, thus, reduces $\mathrm{pc} \mathrm{InsP}_{6}$ degradation $[2,6,7]$. Reducing intestinal $\mathrm{pH}$ might counteract effects of high dietary $\mathrm{Ca}$ concentrations. Ca salts of organic acids like Ca-formate are known to have a lower buffer capacity than $\mathrm{CaCO}_{3}$ [8]. Hence, replacing $\mathrm{CaCO}_{3}$ by $\mathrm{Ca}$-formate might compensate the $\mathrm{pH}$ increase caused by $\mathrm{CaCO}_{3}$ supplementation and thereby increase $\mathrm{InsP}_{6}$ degradation and, as a consequence of changing the Ca source, affect the microbial community. Solubility of dietary $\mathrm{Ca}$ might also influence $\mathrm{P}$ utilization through $\mathrm{Ca}-\mathrm{InsP}_{6}$ complexes or other mechanisms. Complexation of $\mathrm{Ca}$ and $\mathrm{InsP}_{6}$ was shown to be increased at pH 5 and higher [9]. Using Ca sources with higher solubility than that of $\mathrm{CaCO}_{3}$ might allow for a higher $\mathrm{Ca}$ absorption in the proximal section of the small intestine and thus reduce the amount of $\mathrm{Ca}$ cations available for Ca-InsP $\mathrm{P}_{6}$ complex formation.

A decrease in $\mathrm{pH}$ could also be achieved by adding formic acid to diets. As reviewed by Kim et al. [10], supplementation of organic acids was reported to decrease $\mathrm{pH}$ particularly in the crop, with some studies describing decreased $\mathrm{pH}$ up to the ileum. The organic acid formic acid, was reported to affect the microbial community and lead to increased performance and nutrient digestibility in broiler chickens [10]. Likely, the addition of formic acid to $\mathrm{CaCO}_{3}$-containing diets and the use of
Ca-formate influences the microbial community in the digestive tract, possibly through changes in digesta $\mathrm{pH}$ $[11,12]$. Therefore, it is possible that different microbiota composition is involved in causing the observed effects of $\mathrm{Ca}$ sources, organic acid supplementation, and Ca levels on P utilization.

The present study was conducted to investigate effects of diet acidification, dietary $\mathrm{Ca}$, and phytase supplementation on the microbiota of the crop and the terminal small intestine of broiler chickens based on target amplicon sequencing of DNA, and to study consequences on pc InsP $_{6}$ disappearance, and pc $\mathrm{P}$ and $\mathrm{Ca}$ digestibility. We used a $3 \times 2 \times 2$ factorial design for the experiment (Table 1) with two Ca levels (5.6 and $8.2 \mathrm{~g} / \mathrm{kg}$ dry matter) and two phytase supplementation levels ( 0 and 1500 FTU/kg). The third factor was the addition of $6 \mathrm{~g}$ formic acid/ $\mathrm{kg}$ to $\mathrm{CaCO}_{3}$-containing diets or replacing $\mathrm{CaCO}_{3}$ by $\mathrm{Ca}-$ formate, which is termed "acidification" herein. By now, most studies only investigated one or two of these factors, making potential interactions between the three factors impossible to detect. This makes the present study the first to examine the influence of phytase and acidifying ingredients with different $\mathrm{Ca}$ levels on $\mathrm{P}$ utilization following $\mathrm{Ins}_{6}$ degradation, the microbial community, and potential linkages between all traits. To elucidate the underlying mechanisms, $\mathrm{pH}$ and inositol phosphate (InsP) isomers in the digesta of the crop, gizzard, and terminal small intestine were analyzed. It was hypothesized that replacing $\mathrm{CaCO}_{3}$ by $\mathrm{Ca}$-formate or adding formic acid to $\mathrm{CaCO}_{3}$-containing diets decreases the $\mathrm{pH}$, influences the microbial community, and increases InsP $_{6}$ degradation and $\mathrm{P}$ digestibility.

Table 1 Description of 12 dietary treatments in a $3 \times 2 \times 2$ experimental design

\begin{tabular}{lcl}
\hline Acidification & $\begin{array}{l}\text { Ca level } \\
\text { (g/kg dry matter) }\end{array}$ & $\begin{array}{l}\text { Phytase supplementation } \\
\text { (FTU/kg) }\end{array}$ \\
\hline $\mathrm{CaCO}_{3}$ & 5.6 & 0 \\
& 8.2 & 1500 \\
& & 0 \\
$\mathrm{CaCO}_{3}+$ formic acid & 5.6 & 0 \\
& & 1500 \\
& 8.2 & 0 \\
$\mathrm{Ca}^{-f o r m a t e}$ & & 1500 \\
& 5.6 & 0 \\
& & 1500 \\
& 8.2 & 0 \\
& & 1500 \\
\hline
\end{tabular}




\section{Results}

The initial group weight at the beginning of feeding the experimental diets, on day 16 of life, was similar for all treatments, at $9604 \mathrm{~g} /$ pen (standard deviation = $15 \mathrm{~g} /$ pen, $P=0.183$ ). The experimental period ended on day 21 and day 22 post-hatch for half of the replicate pens of each treatment. Mortality was low $(0.6 \%$ of all animals) and not related to any treatment (six cases in six different treatments).

\section{Growth performance}

The average daily gain (ADG) and average daily feed intake (ADFI) during the experimental period were lower compared to other treatments when the $\mathrm{Ca}$ level was high and no phytase was supplemented $(P<0.001$; Fig. 1, Table S1). The ADFI was significantly lower for Ca-formate compared to $\mathrm{CaCO}_{3}$ and $\mathrm{CaCO}_{3}$ + formic acid $(P=0.002)$. Phytase supplementation increased the gain to feed ratio (G:F) by $0.04 \mathrm{~g} / \mathrm{g}(P<0.001)$. Further effects on growth performance were not significant.

\section{$\mathrm{pH}$ in the digestive tract}

The contents of crop, gizzard, and posterior small intestine were obtained immediately after slaughter of the birds. In the crop content, the highest $\mathrm{pH}$ of 5.5 was observed for $\mathrm{CaCO}_{3}$. Crop pH was decreased by 0.6 and 0.3 units for $\mathrm{CaCO}_{3}+$ formic acid and Ca-formate, respectively, compared to $\mathrm{CaCO}_{3}(P<0.001$; Fig. 2, Table S2). With a 0.1 -unit increase, crop pH was marginally but significantly higher for the high compared to the low $\mathrm{Ca}$ level. In the gizzard, phytase supplementation increased $\mathrm{pH}$ by 0.2 units $(P<0.001)$ and decreased $\mathrm{pH}$ by 0.1 units $(P=0.005)$ at the low and high $C a$ level, respectively. In the ileum, phytase supplementation increased $\mathrm{pH}$ by 0.8 units at the high Ca level $(P<0.001)$ but had no significant effect at the low Ca level.

\section{Microbial community}

In content of both the crop and the ileum, mainly Lactobacillus species, including $L$. johnsonii, L. crispatus, $L$. reuteri, L. gallinarum, and $L$. vaginalis, were identified (Fig. 3 and Fig. 4). Streptococcus alactolyticus was highly abundant in the crop and the ileum for diets with $\mathrm{CaCO}_{3}$ at the low $\mathrm{Ca}$ level, irrespective of phytase supplementation. This was reflected by a high similarity between $\mathrm{CaCO}_{3}$ treatments at the low $\mathrm{Ca}$ level and a separation of these treatments from the other diets in a cluster analysis (Fig. S1). Permutational multivariate analysis of variance (PERMANOVA) analyses (Table S3) revealed that the microbial communities in the crop and the ileum were significantly affected by all the main effects $(P \leq 0.034)$, with no interaction being significant. The microbial community in birds receiving $\mathrm{CaCO}_{3}$ differed significantly in both sections of the digestive
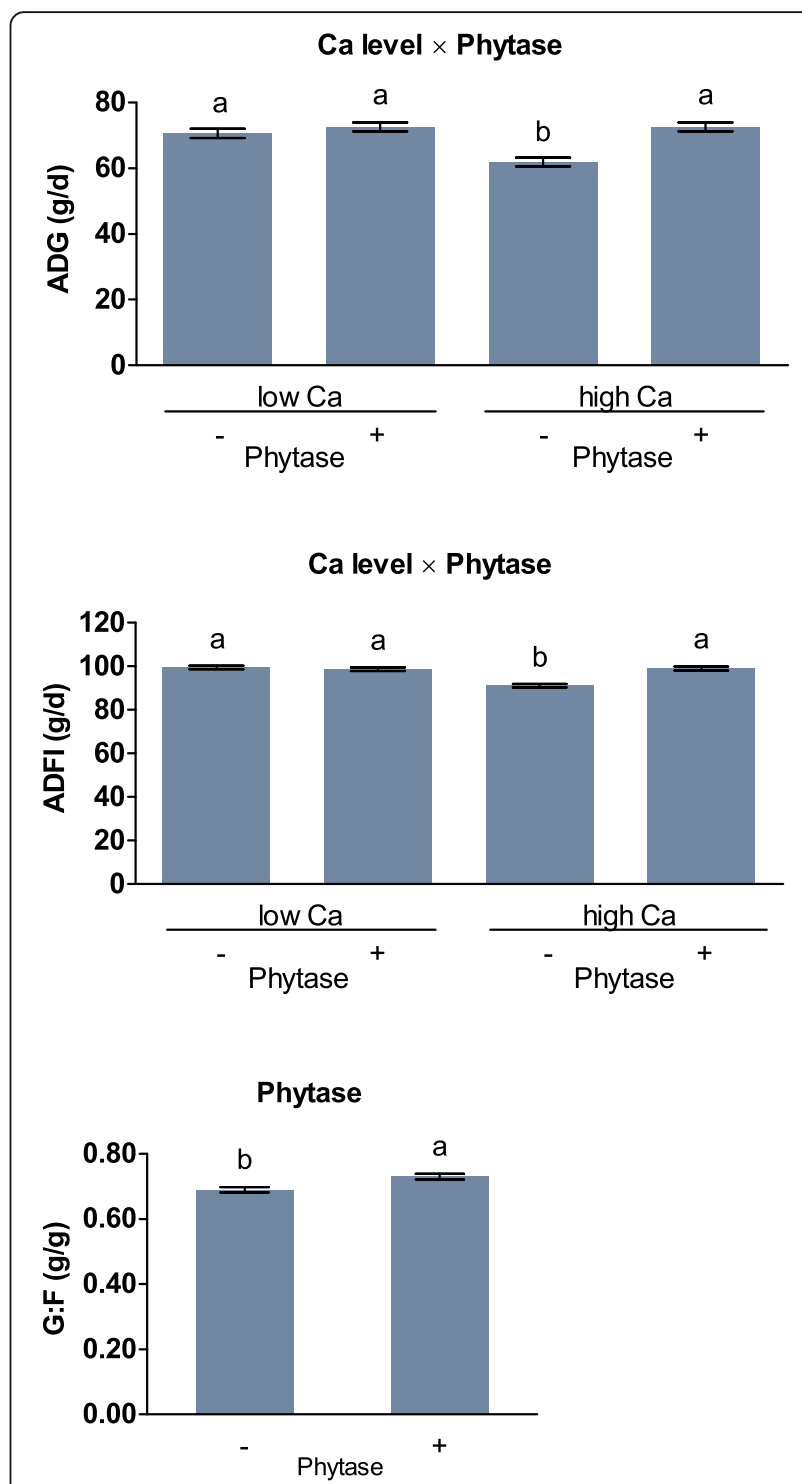

Fig. 1 Average daily gain (ADG), average daily feed intake (ADFI), and the gain to feed ratio (G:F) of broiler chickens fed with differently acidified diets with low and high Ca levels and without $(-)$ or with (+) supplementation of 1500 FTU phytase/kg fed from day 16 of life to the end of the experiment on day 21 or 22 for half of the replicate pens of each treatment. Only significant $(P<0.050)$ effects are shown. Columns within a statistical comparison not sharing the same letter are significantly different $(P \leq 0.050)$. Details of the statistical evaluations are shown in Table S1

tract compared to $\mathrm{CaCO}_{3}+$ formic acid or $\mathrm{Ca}$-formate $(P \leq 0.005)$.

In the crop content, between 34 and $53 \%$ of the detected relative abundance of microorganisms corresponded to operative taxonomic unit (OTU) 1 (L. johnsonii) and between 11 and $29 \%$ to OTU2 ( $L$. gallinarum). We conducted analyses of variance (ANOVA) to get information on treatment effects on single OTUs being aware that explanatory power is 

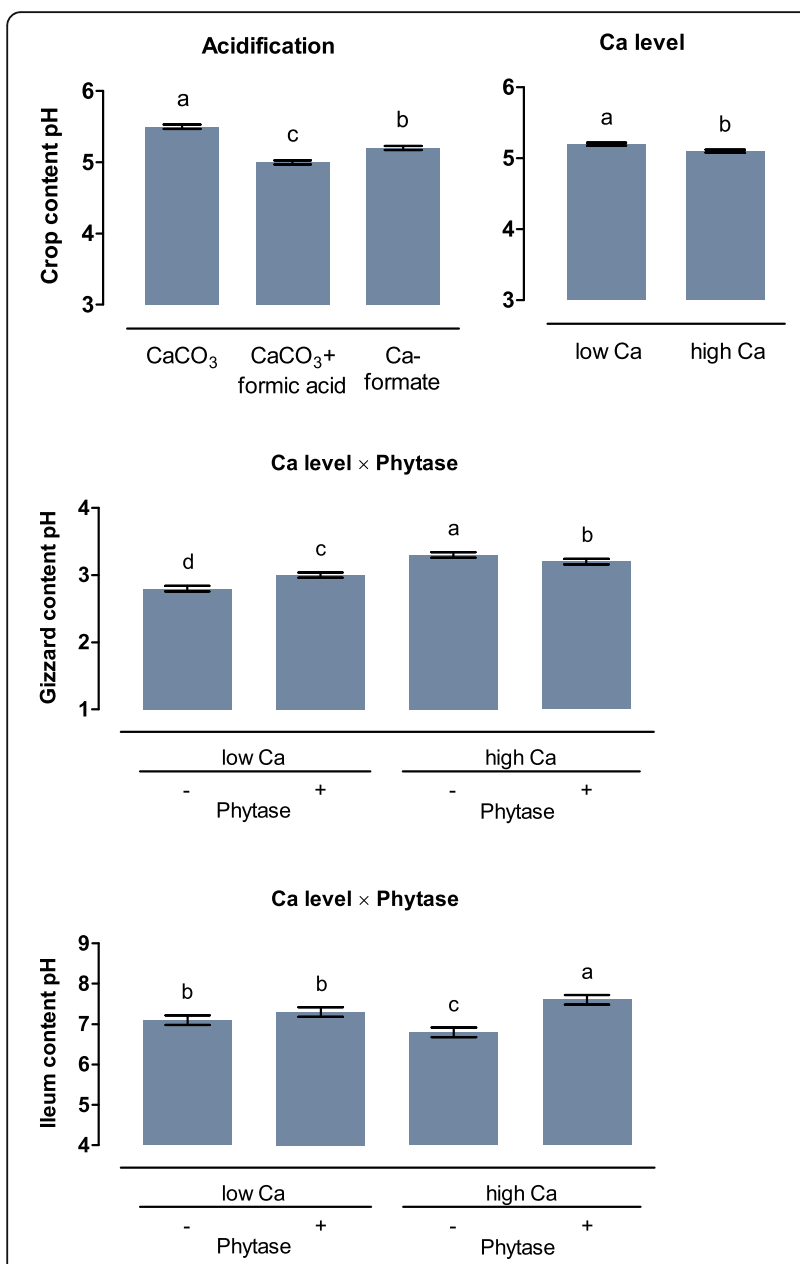

Fig. $2 \mathrm{pH}$ in the crop, gizzard, and ileum of broiler chickens fed with differently acidified diets with low and high Ca levels and without $(-)$ or with (+) supplementation of 1500 FTU phytase/kg. Only significant $(P<0.050)$ effects are shown. Columns within a statistical comparison not sharing the same letter are significantly different $(P \leq 0.050)$. Details of the statistical evaluations are shown in Table S2

partly impinged by physiological interrelationships between microorganisms. Abundance of OTU1 (L. johnsonii) was higher for Ca-formate when phytase was supplemented $(P \leq 0.050)$ (Table S4). The abundance of OTU1 increased for Ca-formate at the high Ca level. $\mathrm{CaCO}_{3}$ increased the abundance of the OTUs assigned to $L$. reuteri (OTU9, OTU11, OTU15, and OTU19, $P \leq$ 0.001). The high $\mathrm{Ca}$ level led to an increased abundance of OTU4 $(P=0.005)$, OTU9 $(P=0.036)$, and OTU11 $(P<0.001)$, which were assigned to $L$. reuteri. Phytase supplementation increased the abundance of OTU9, OTU11, and OTU13 (L. reuteri). Further significant influences on OTUs assigned to $L$. vaginalis, L. gallinarum, S. alactolyticus, Gallibacterium sp., Unc. Bacterium, and Unc. Firmicutes are shown in Table S4 and Table S5. Crop pH was positively correlated with seven out of nine OTUs assigned to $L$. reuteri $(P \leq 0.027$, Table S6, Fig. S2). Similar to the crop, the most abundant OTUs in the ileum were OTU1 (L. johnsonii, 24-46\%) and OTU2 (L. gallinarum, 15-41\%). Phytase supplementation increased the abundance of OTU1 $(P=0.040)$ and OTU2 $(P=0.015)$. The abundance of OTU2 was increased in the ileum of chicken fed with the high $\mathrm{Ca}$ level diets $(P=0.009)$. The abundance of OTUs assigned to $L$. reuteri (OTU6, OTU15, and OTU18, $P \leq 0.049$ ) were decreased for $\mathrm{Ca}$-formate and the abundance of OTU19 ( $L$. reuteri, $P=0.049$ ) was increased for $\mathrm{CaCO}_{3}$.

Six significant correlations $(P \leq 0.038)$ with OTUs assigned to $L$. johnsonii, L. gallinarum, and $L$. reuteri were determined for InsP $_{6}$ concentration in the ileum, pc P digestibility, and pc $\operatorname{InsP}_{6}$ disappearance (OTU1, OTU2, OTU4, OTU9, OTU11, and OTU13) (Table S7, Fig. S3). Correlations with OTUs assigned to Unc. Firmicutes, L. reuteri, S. alactolyticus, and Gallibacterium sp. were significant in five cases for $\mathrm{pH}$ in the ileum (OTU7, OTU9, OTU10, OTU11, and OTU23). Correlations with concentrations of myo-inositol in the ileum were significant for OTUs assigned to L. johnsonii, L. gallinarum, and $L$. reuteri (OTU1, OTU2, OTU9, OTU11, and OTU13).

\section{Functional prediction}

The broad classification hierarchy of KEGG pathways of functions showed that same P-related pathways were significantly influenced in the crop and the ileum (Fig. 5, Table S8). No interaction related to genes connected to InsP metabolism was significant in the crop and the ileum. In the crop, genes encoding for InsP metabolism were higher in the $\mathrm{CaCO}_{3}$ than in the $\mathrm{CaCO}_{3}+$ formic acid and $\mathrm{Ca}$-formate treatments $(P \leq 0.001)$ and more abundant at the low than at the high Ca level $(P=$ 0.007). In the ileum, the abundance of genes related to InsP metabolism was lower in the Ca-formate treatment than in the $\mathrm{CaCO}_{3}$ and $\mathrm{CaCO}_{3}+$ formic acid treatments $(P \leq 0.011)$ and not influenced by $\mathrm{Ca}$ level. Phytase supplementation had no effect on InsP metabolism pathways in the crop and the ileum. Other significantly influenced pathways were mineral absorption, the phosphotransferase system, the phosphatidylinositol signaling system, and phosphonate and phosphinate metabolism in the crop and the ileum. Phytase supplementation decreased the abundances of genes related to the phosphonate and phosphinate metabolism $(P=0.048)$ in the crop and increased the abundances of genes related to the phosphatidylinositol signaling system in the ileum $(P=$ 0.031 ). The other pathways were influenced by acidification, $\mathrm{Ca}$ level, or the two-way interaction between acidification and $\mathrm{Ca}$ level with no apparent pattern in changes. 

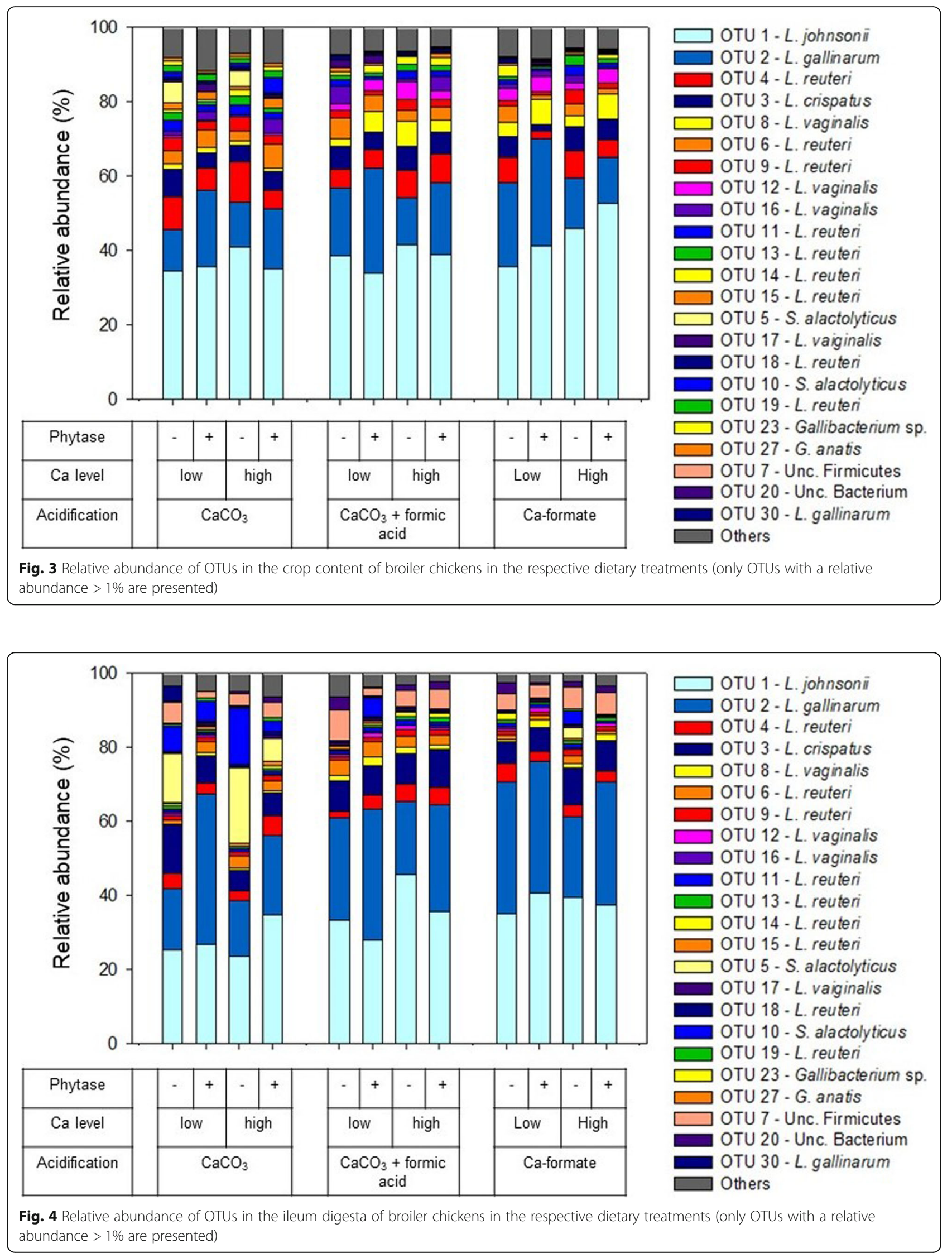


\section{Crop}
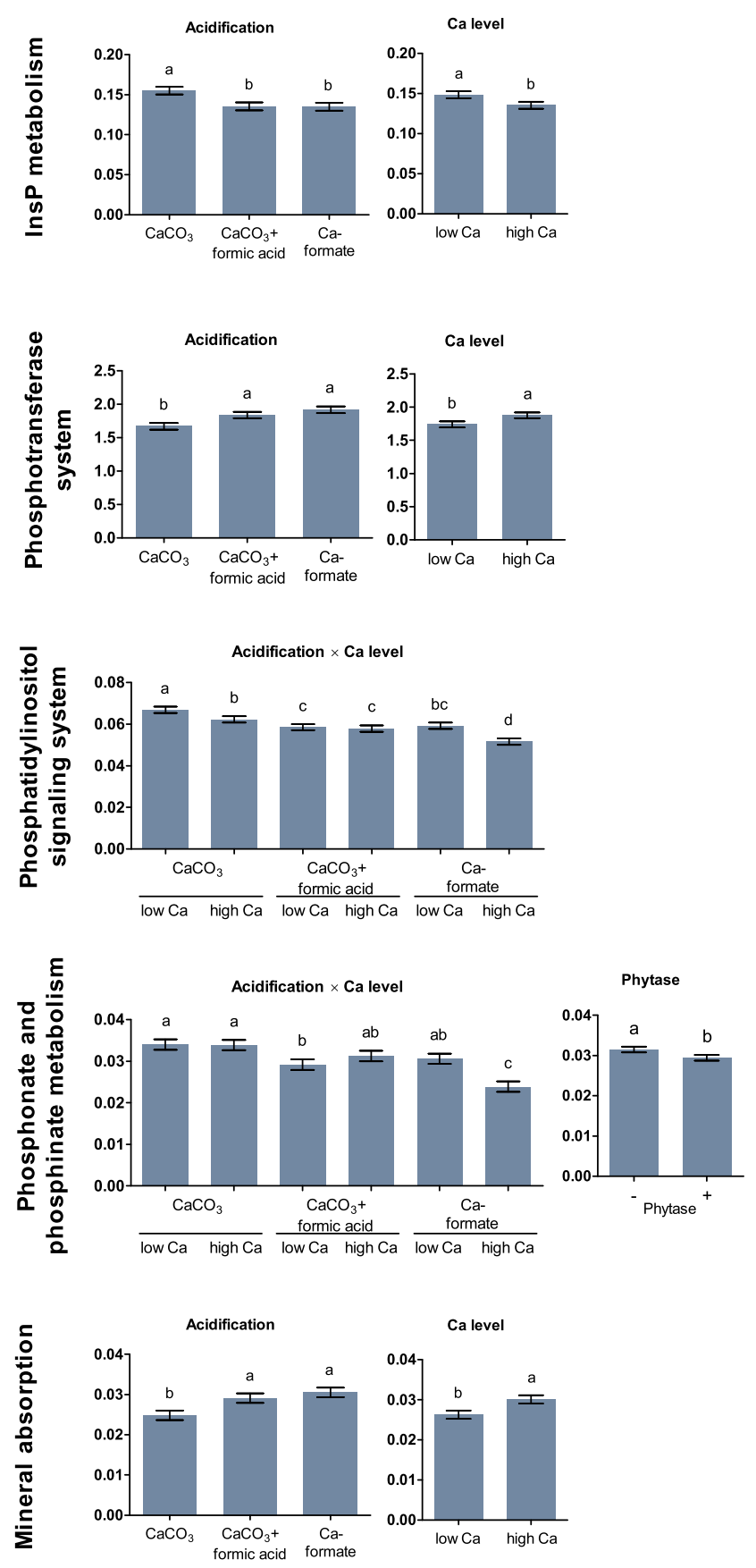

\section{Ileum}
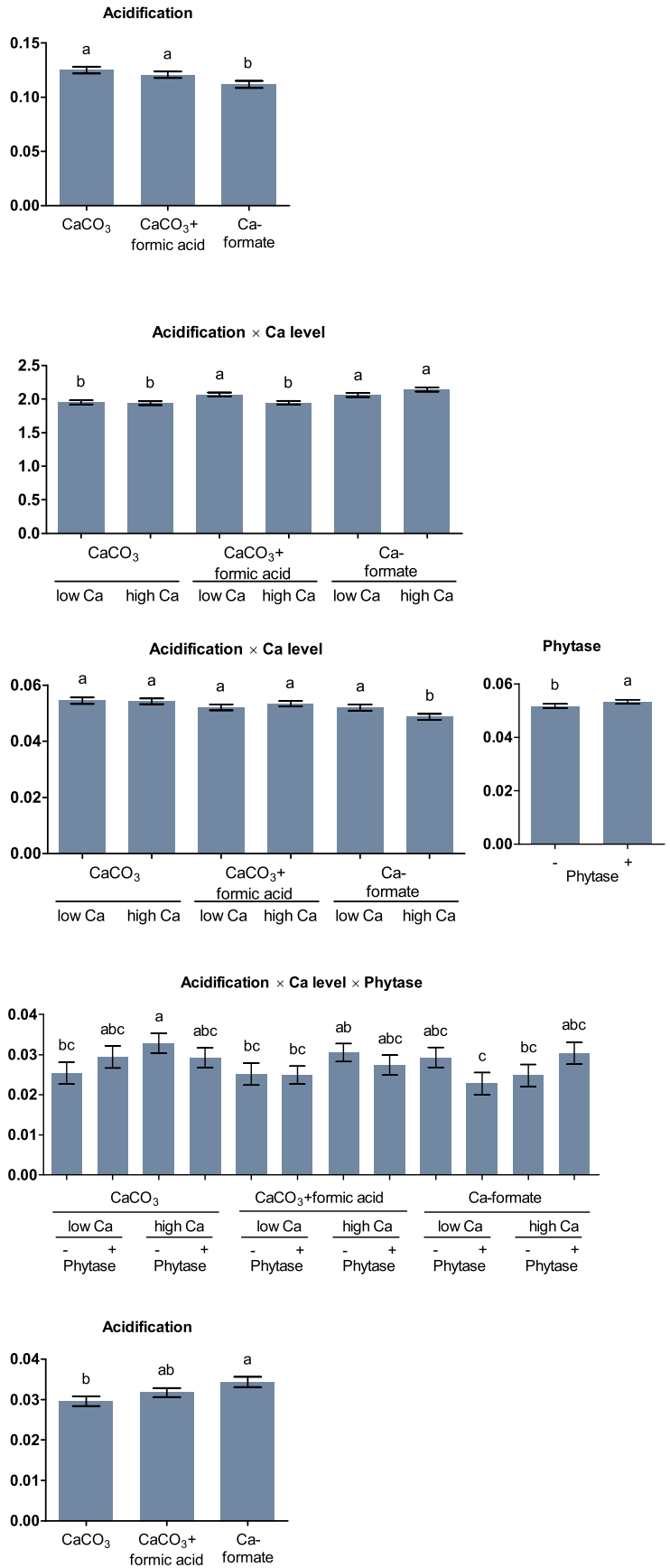

Fig. 5 Relative proportion of genes assigned to P-related KEGG pathways in the crop content and the ileum digesta of broiler chickens fed with differently acidified diets with low and high Ca levels without (-) and with (+) supplementation of 1500 FTU phytase/kg. Only significantly influenced pathways are presented $(P<0.050)$. Columns within a statistical comparison not sharing the same letter are significantly different $(P \leq$ 0.050). Details of the statistical evaluations are shown in Table $S 8$

Within the category of InsP metabolism, increasing the $\mathrm{Ca}$ level reduced abundance of genes coding for myo-inositol-1(or 4)-monophosphatase in the $\mathrm{CaCO}_{3}$ and Ca-formate treatments $(P \leq 0.018)$, but not in the
$\mathrm{CaCO}_{3}+$ formic acid treatment $(P=0.520)$ in the crop (Fig. 6, Table S9). In the ileum, myo-inositol-1(or 4)monophosphatase was increased by phytase supplementation $(P=0.040)$. Increasing dietary Ca had no effect on 


\section{Crop}

\section{Ileum}
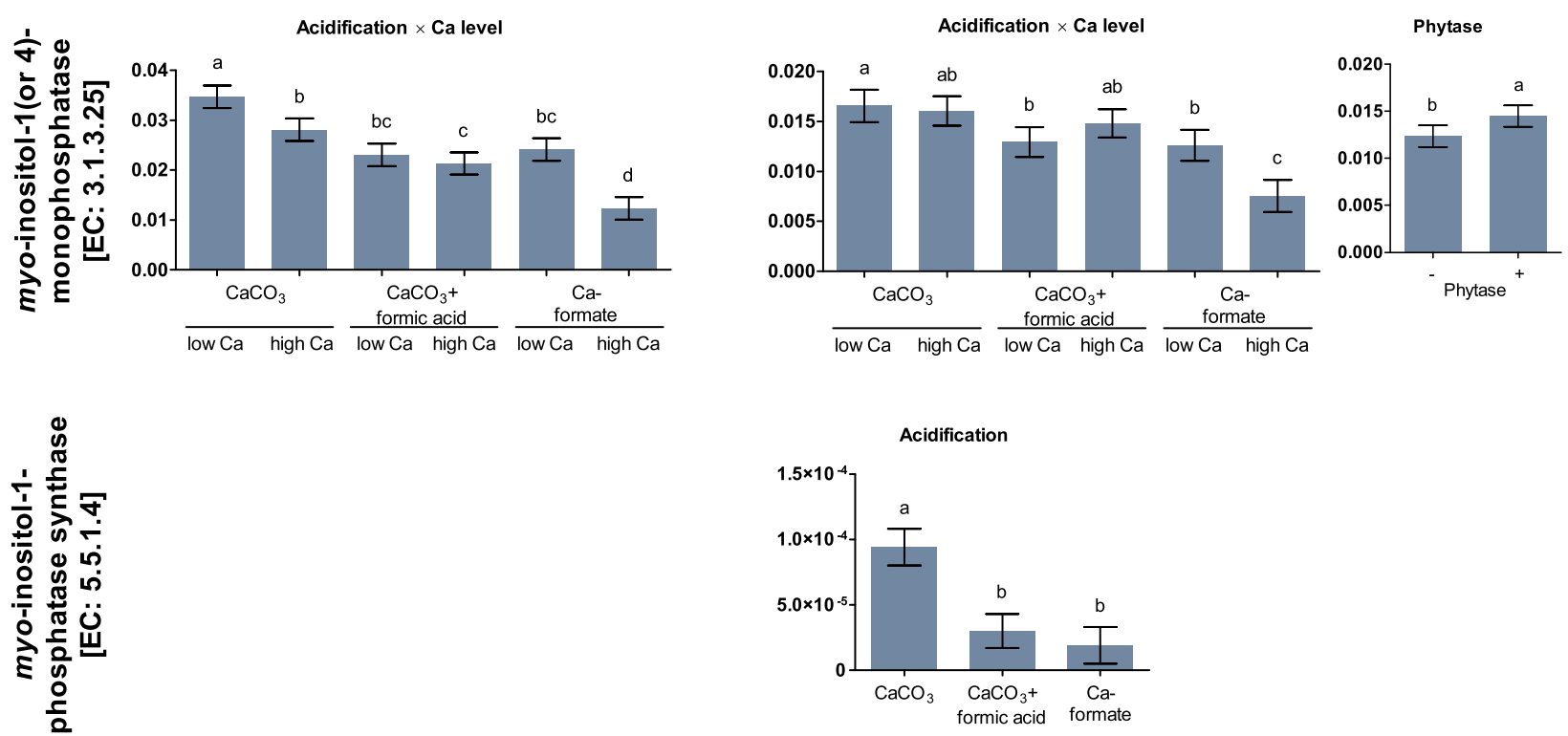

Fig. 6 Relative proportion of genes assigned to enzymes related to inositol phosphate and myo-inositol degradation listed in the KEGG database in the crop content and the ileum digesta of broiler chickens fed with differently acidified diets with low and high Ca levels without (-) and with (+) supplementation of $1500 \mathrm{FTU}$ phytase/kg. Only significantly influenced enzymes are presented $(P<0.050)$. Columns within a statistical comparison not sharing the same letter are significantly different $(P \leq 0.050)$. Details of the statistical evaluations are shown in Table 59

myo-inositol-1(or 4)-monophosphatase in the $\mathrm{CaCO}_{3}$ and $\mathrm{CaCO}_{3}+$ formic acid treatments $(P \geq 0.269)$ and decreased myo-inositol-1(or 4)-monophosphatase in the Ca-formate treatment $(P=0.008)$. Myo-inositol-1-phosphate synthase coding genes were lower in the $\mathrm{CaCO}_{3}+$ formic acid and Ca-formate treatments than in the $\mathrm{CaCO}_{3}$ treatment in the ileum $(P \leq 0.001)$. Other genes annotated to InsP and myo-inositol degradation in the KEGG database were not influenced by the treatments used in this study.

Ins $\mathrm{P}_{6}$ disappearance and prececal digestibility of $\mathrm{P}$ and $\mathrm{Ca}$ Contents of crop, gizzard, and ileum were analyzed for $\mathrm{InsP}_{6}$ and degradation products, $\mathrm{P}, \mathrm{Ca}$, and titanium dioxide. $\mathrm{Ins}_{6}$ disappearance and mineral digestibility were calculated using titanium dioxide as the undigestible reference. In the crop, Ca level did not affect $\mathrm{InsP}_{6}$ disappearance $(P=0.536)$ when no phytase was supplemented (Fig. 7; Table S10). At the high Ca level, the effects of phytase supplementation on $\mathrm{InsP}_{6}$ disappearance in the crop increased by 6 percentage points (pp) to $37 \%(P=0.025)$. Phytase supplementation increased InsP $\mathrm{P}_{6}$ disappearance in the $\mathrm{CaCO}_{3}$ treatments with and without formic acid by 20 and 37 pp., respectively $(P<0.001)$, but not in the Ca-formate treatment $(P=0.090)$.

Phytase supplementation increased $\mathrm{pc} \mathrm{InsP}_{6}$ disappearance $(P<0.001)$ to approximately $80 \%$, irrespective of the dietary Ca level. Without phytase supplementation, pc InsP $_{6}$ disappearance was $9 \mathrm{pp}$. higher for the low compared to the high $\mathrm{Ca}$ level $(P<0.001)$. Ca level had no effect on pc Ins $\mathrm{P}_{6}$ disappearance for $\mathrm{CaCO}_{3}+$ formic acid, but the high $\mathrm{Ca}$ level decreased pc $\mathrm{InsP}_{6}$ disappearance by $4 \mathrm{pp}$. for $\mathrm{CaCO}_{3}(P=0.047)$ and by $10 \mathrm{pp}$. for Ca-formate $(P=0.016)$. Increasing dietary Ca decreased pc $\mathrm{P}$ digestibility. This effect was more pronounced for Ca-formate, with 12 pp. $(P<0.001)$, than for $\mathrm{CaCO}_{3}$ and $\mathrm{CaCO}_{3}+$ formic acid, with $7 \mathrm{pp}$. each $(P<0.001)$. The three-way interaction was significant for pc $\mathrm{Ca}$ digestibility $(P=0.012$, Fig. 8$)$. The pc $\mathrm{Ca}$ digestibility in $\mathrm{CaCO}_{3}$ and $\mathrm{CaCO}_{3}$-formate was increased by phytase supplementation at the low Ca level $(P \leq 0.012)$ but was not affected at the high $\mathrm{Ca}$ level $(P \geq 0.160)$. Phytase supplementation increased and decreased pc Ca digestibility for $\mathrm{CaCO}_{3}+$ formic acid at the low and high $\mathrm{Ca}$ level, respectively $(P \leq 0.002)$.

\section{Inositol phosphate isomer and myo-inositol concentrations} Significant interactions between acidification and phytase supplementation were detected for Ins $\mathrm{P}_{6}$ and two $\mathrm{InsP}_{5}$ isomers in the crop $(P<0.001$; Table S11). Decrease in concentrations of $\mathrm{InsP}_{6}$ and $\mathrm{InsP}_{5}$ isomers upon phytase supplementation was most pronounced in the $\mathrm{CaCO}_{3}+$ formic acid treatment and less in the $\mathrm{CaCO}_{3}$ and the Ca-formate treatments. Myo-inositol concentrations in the crop were not affected. 

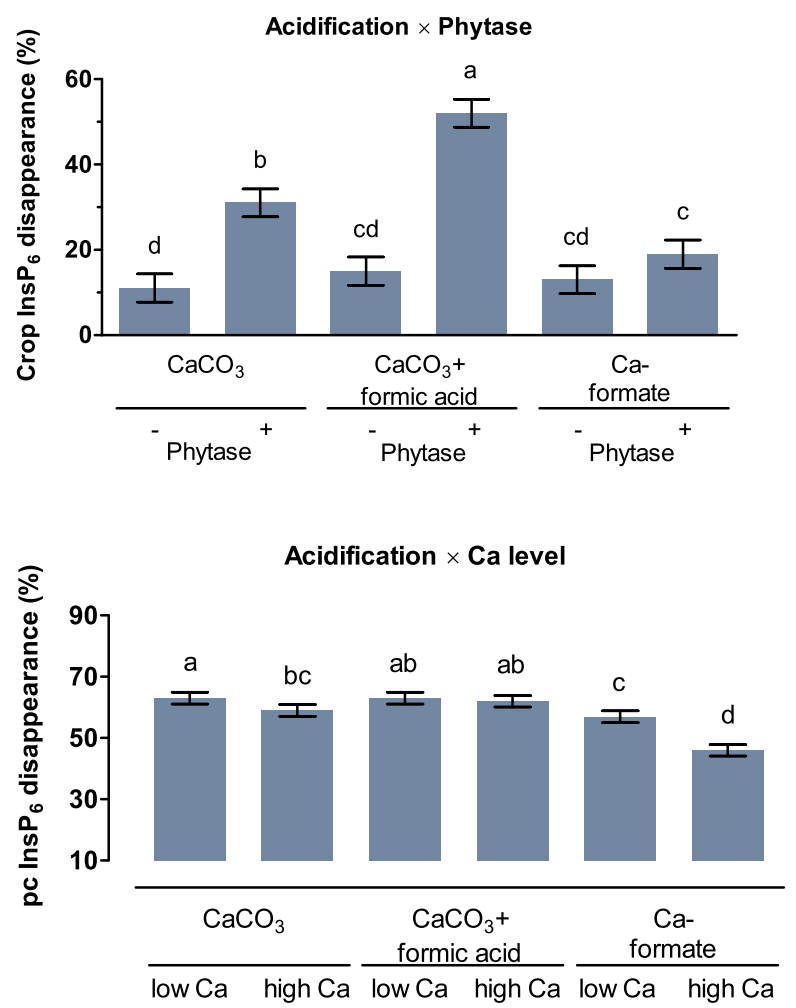

Acidification $\times$ Ca level

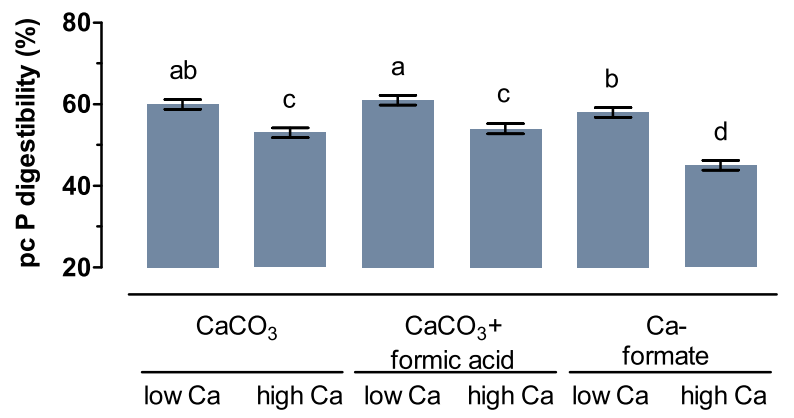

Ca level $\times$ Phytase

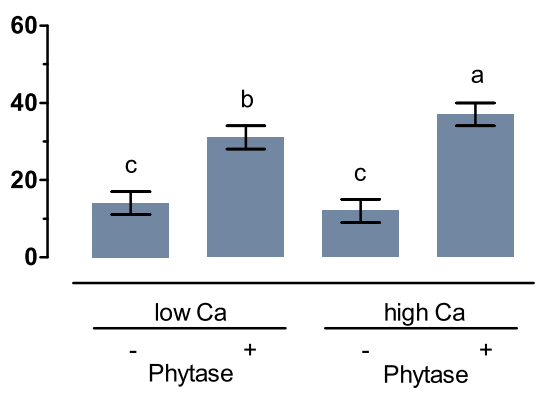

Ca level $\times$ Phytase

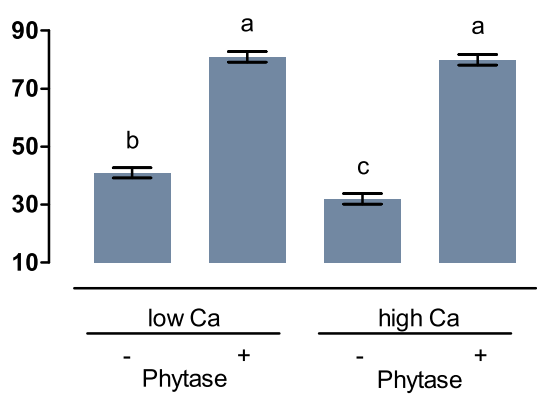

Phytase

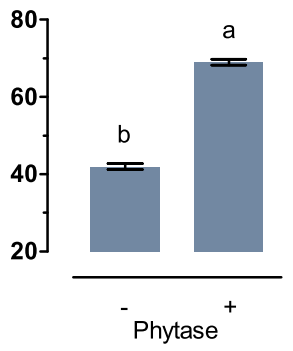

Acidification $\times$ Ca level $\times$ Phytase

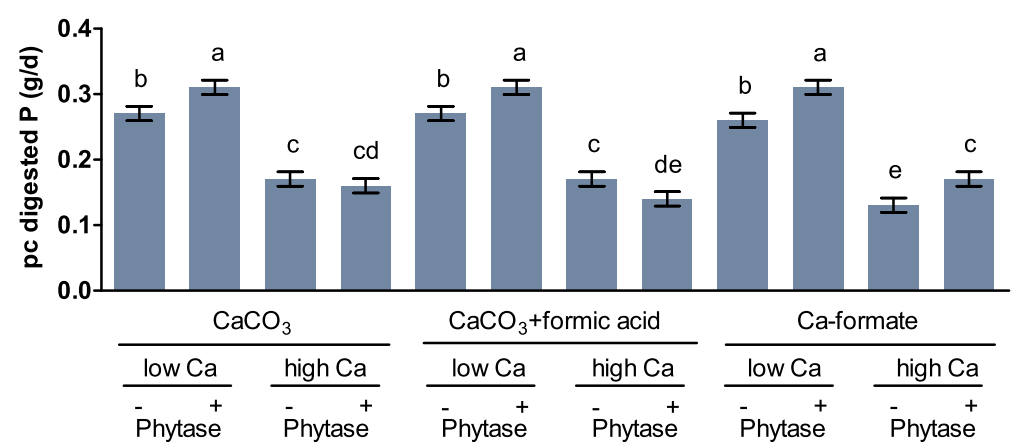

Fig. 7 (See legend on next page.) 
(See figure on previous page.)

Fig. 7 Ins $\mathrm{P}_{6}$ disappearance in the crop, prececal $(\mathrm{pc}) \mathrm{Ins}_{6}$ disappearance, $\mathrm{pc} \mathrm{P}$ digestibility, and amount of pc digested $\mathrm{P}$ of broiler chickens fed with differently acidified diets with low and high Ca levels without (-) and with (+) supplementation of $1500 \mathrm{FTU}$ phytase/kg. Only significant $(P<0.050)$ effects are shown. Columns within a statistical comparison not sharing the same letter are significantly different $(P \leq 0.050)$. Details of the statistical evaluations are shown in Table S10

In the gizzard, InsP $\mathrm{P}_{6}$ concentrations were lower in diets with supplemented phytase compared to those without $(P<0.001$, Table S12). Highest InsP 6 concentrations were found in the Ca-formate treatment without phytase supplementation. Phytase supplementation decreased concentrations of InsP $_{5}$ isomers below level of detection, while making some $\operatorname{InsP}_{4}$ and $\mathrm{InsP}_{3}$ isomers detectable. Phytase supplementation increased myo-inositol concentrations to a greater extent at the low $\mathrm{Ca}$ level compared to the high $\mathrm{Ca}$ level $(P=0.022)$. Acidification had no effect on myo-inositol concentrations.

In the ileum, treatment effects on $\mathrm{InsP}_{6}$ concentration were inverse to those on $\mathrm{pc} \mathrm{InsP}_{6}$ disappearance (Table S13). Phytase supplementation had no effect on $\operatorname{Ins}(1,2$, $4,5,6) \mathrm{P}_{5}$ concentration, but increased $\operatorname{Ins}(1,2,3,4,5) \mathrm{P}_{5}$ concentrations and decreased $\operatorname{Ins}(1,2,3,4,6) \mathrm{P}_{5}$ concentrations in most cases. Concentrations of $\operatorname{InsP}_{4}$ and $\operatorname{InsP}_{3 x}$ were increased upon phytase supplementation $(P<$
0.001). Ins $(1,2,3,4,5) \mathrm{P}_{5}$ concentrations were highest at the high $\mathrm{Ca}$ level for $\mathrm{CaCO}_{3}$ + formic acid and both $\mathrm{Ca}$ levels for $\mathrm{Ca}$-formate when phytase was supplemented. Concentrations of $\operatorname{Ins}(1,2,3,4) \mathrm{P}_{4}$ and $\operatorname{InsP}_{3 x}$ were high when phytase was supplemented to $\mathrm{CaCO}_{3}+$ formic acid and $\mathrm{Ca}$-formate at the high $\mathrm{Ca}$ level. An increase in myo-inositol concentrations upon phytase supplementation was more pronounced in the ileum at the low compared to the high $\mathrm{Ca}$ level. The highest myo-inositol concentration was determined for $\mathrm{CaCO}_{3}+$ formic acid $(P \leq 0.003)$ with no difference between $\mathrm{CaCO}_{3}$ and $\mathrm{Ca}$ formate $(P=0.150)$.

\section{Discussion}

Effects of phytase on InsP $_{6}$ degradation and subsequent $\mathrm{P}$ utilization differ considerably between studies. Possible explanations include the use of acidifying ingredients in the diet and different $\mathrm{Ca}$ levels affecting the $\mathrm{pH}$,

\section{Acidification $\times$ Ca level $\times$ Phytase}
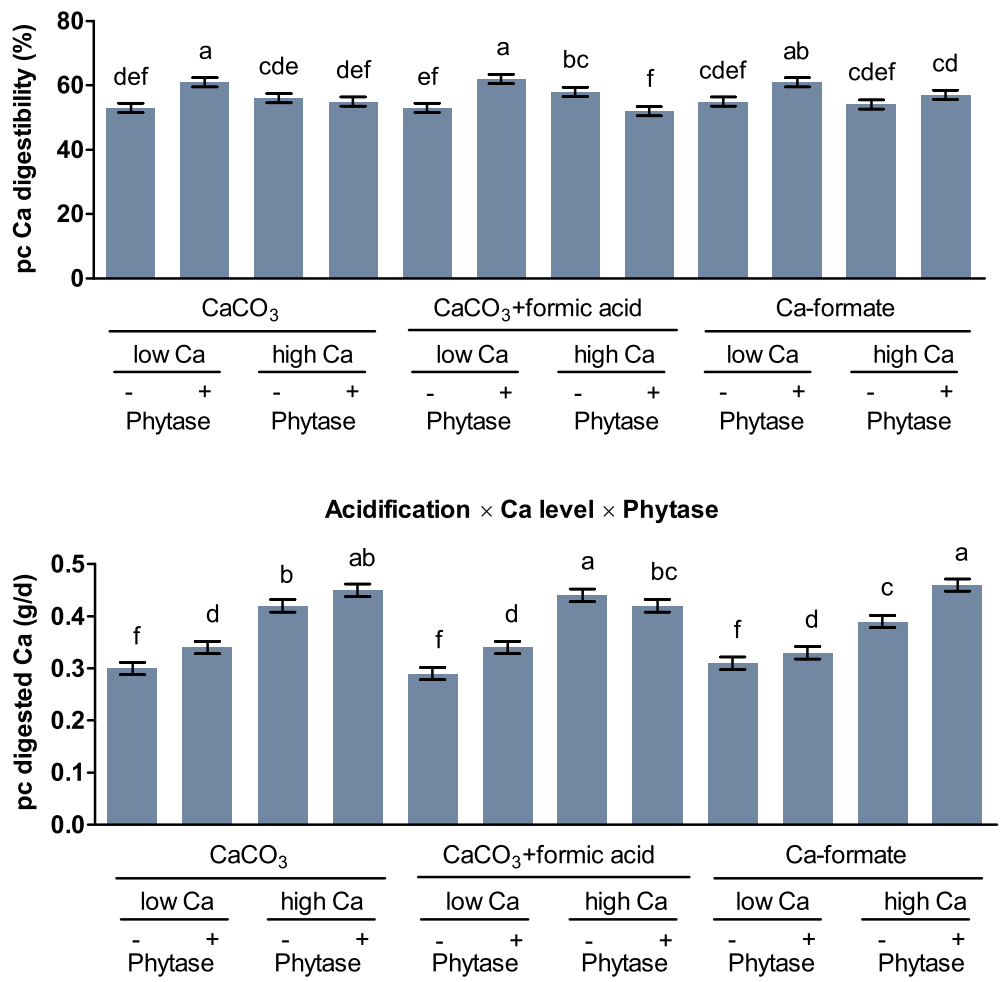

Fig. 8 Prececal (pc) Ca digestibility and amount of pc digested Ca of broiler chickens fed with differently acidified diets with low and high Ca levels without $(-)$ and with $(+)$ supplementation of $1500 \mathrm{FTU}$ phytase/kg. Only significant $(P<0.050)$ effects are shown. Columns within a statistical comparison not sharing the same letter are significantly different $(P \leq 0.050)$. Details of the statistical evaluations are shown in Table S10 
phosphatase-producing bacteria, the probability that InsP $_{6}$ complexes are formed, and the efficacy of phytases in the digestive tract. Most studies only investigated one factor, making potential interactions impossible to detect. This study first-time investigated influences of phytase and acidifying ingredients with different $\mathrm{Ca}$ levels and connects effects on the microbial community and $\mathrm{P}$ utilization following $\mathrm{InsP}_{6}$ degradation to find linkages between responses. We hypothesized that replacing $\mathrm{CaCO}_{3}$ by $\mathrm{Ca}$-formate or adding formic acid to $\mathrm{CaCO}_{3}$-containing diets decreases the $\mathrm{pH}$, influences the microbial community and its functionality, and increases Ins $\mathrm{P}_{6}$ degradation and $\mathrm{P}$ digestibility.

\section{Crop}

\section{Crop microbiota and inositol phosphate degradation}

In the crop, dietary treatments influenced both the microbial community and $\mathrm{InsP}_{6}$ degradation. This could have been independent effects or causal linkages. Adding formic acid to $\mathrm{CaCO}_{3}$ or replacing $\mathrm{CaCO}_{3}$ with $\mathrm{Ca}$ formate decreased $\mathrm{pH}$ in the crop content and concurrently shifted microbiota composition. A connection between $\mathrm{pH}$ and abundance of OTUs is indicated by correlations (Table S4) but it is not clear whether $\mathrm{pH}$ or other consequences of $\mathrm{Ca}$ level and acidification were causative. The microbial communities of the $\mathrm{CaCO}_{3}+$ formic acid and $\mathrm{Ca}$-formate treatments differed from that of the $\mathrm{CaCO}_{3}$ treatment, while no difference of the microbial community was determined between the $\mathrm{CaCO}_{3}$ + formic acid and Ca-formate treatments. Changes in $\mathrm{pH}$ were not completely concomitant with changes in the microbial community, suggesting that changes in the microbial community were caused by at least one other mechanism in addition to $\mathrm{pH}$ reduction. Likely, different mechanisms had an impact on the microbial community when the $\mathrm{pH}$ was reduced from 5.5 to $5.2\left(\mathrm{CaCO}_{3}\right.$ to $\mathrm{Ca}$-formate $)$ and from $\mathrm{pH} 5.2$ to 4.9 (Ca-formate to $\mathrm{CaCO}_{3}+$ formic acid). The microbial community may also have been affected by formic acid because the applied inclusion of formic acid is known to inhibit certain bacterial species including salmonella [13-15] and can be used as a carbon source by other bacteria [16].

Functional prediction and changes in the relative abundance of some bacteria may suggest an influence of the microbial community on P utilization. Phosphatase activity has been described for microorganisms, including L. johnsonii [17] and strains of L. reuteri [18]. Relative abundance of $L$. johnsonii ranged from 34 to $53 \%$ and depended on acidification and Ca level (Table S12). Hence, treatments probably influenced the contribution of $L$. johnsonii to P utilization and affected other traits of $L$. johnsonii; probiotic characteristics are assigned to $L$. johnsonii, such as reduced adhesion to the epithelial cells and inhibited growth of pathogenic microorganisms in humans [19], and they are further known to positively influence measures related to the immune system of broilers [20]. Relative abundance of OTUs assigned to strains of $L$. reuteri summed up to a range of $6-26 \%$. At the low Ca level, the relative abundance of some OTUs assigned to $L$. reuteri (OTU4, OTU9, OTU11, and OTU13) were less abundant in the crop, which corroborates the finding that $\mathrm{Ca}$ can inhibit the growth of $L$. reuteri [18]. Hayek et al. [18] found that phosphatase activity (probably including phytase) produced by $L$. reuteri depended on strain and presence of chemical elements in a nutrient solution. Ca increased phosphatase activity of all $L$. reuteri strains under investigation. This effect was described to be caused by Ca-dependent activation of active sites of phosphatases, including phytase $[21,22]$. In the present study, it appears possible that lower abundance of most $L$. reuteri strains were compensated by a higher potential to produce phosphatases by $L$. reuteri and other microorganisms at the higher $\mathrm{Ca}$ level when phytase was supplemented. Irrespective of individual bacteria strains, the InsP metabolism and other P-related metabolic pathways of the microbial community in the crop were influenced by acidification and $\mathrm{Ca}$ level. Within InsP metabolism, acidification and Ca level influenced the abundance of genes connected to enzymes involved in degradation of lower InsP isomers and myo-inositol. This strongly indicates that the microbial community contributes to InsP degradation in the crop; however, the extent of this contribution cannot be sufficiently quantified with the available data.

\section{Effect of $\mathrm{pH}$ on Ins $\mathrm{P}_{6}$ disappearance in the crop}

Acidification and Ca level effects were observed in diets with phytase supplementation only. With a value of $55 \%$, the highest $\operatorname{InsP}_{6}$ disappearance in the crop was observed when phytase was supplemented to $\mathrm{CaCO}_{3}+$ formic acid. This effect seems to have been caused by acidification of the crop content by formic acid, which then shifted the $\mathrm{pH}$ closer to the optimum of the phytase used ( $\mathrm{pH}$ optimum of 4.5 according to the product datasheet of the producer). This explanation is supported by a linearly negative relation between crop $\mathrm{pH}$ and $\mathrm{InsP}_{6}$ disappearance in the phytase-supplemented diets (Fig. 9). The regression indicates that InsP $_{6}$ disappearance in the crop was increased by $5.3 \mathrm{pp}$. per each 0.1 -unit reduction of $\mathrm{pH}$ in the crop.

\section{Ca solubility effects}

Different Ca solubility seems to have an influence on InsP $_{6}$ disappearance in the crop, but clear inferences are difficult to make. Higher solubility can make free $\mathrm{Ca}$ cations more available for $\mathrm{Ca}-\mathrm{InsP}_{6}$ complex 


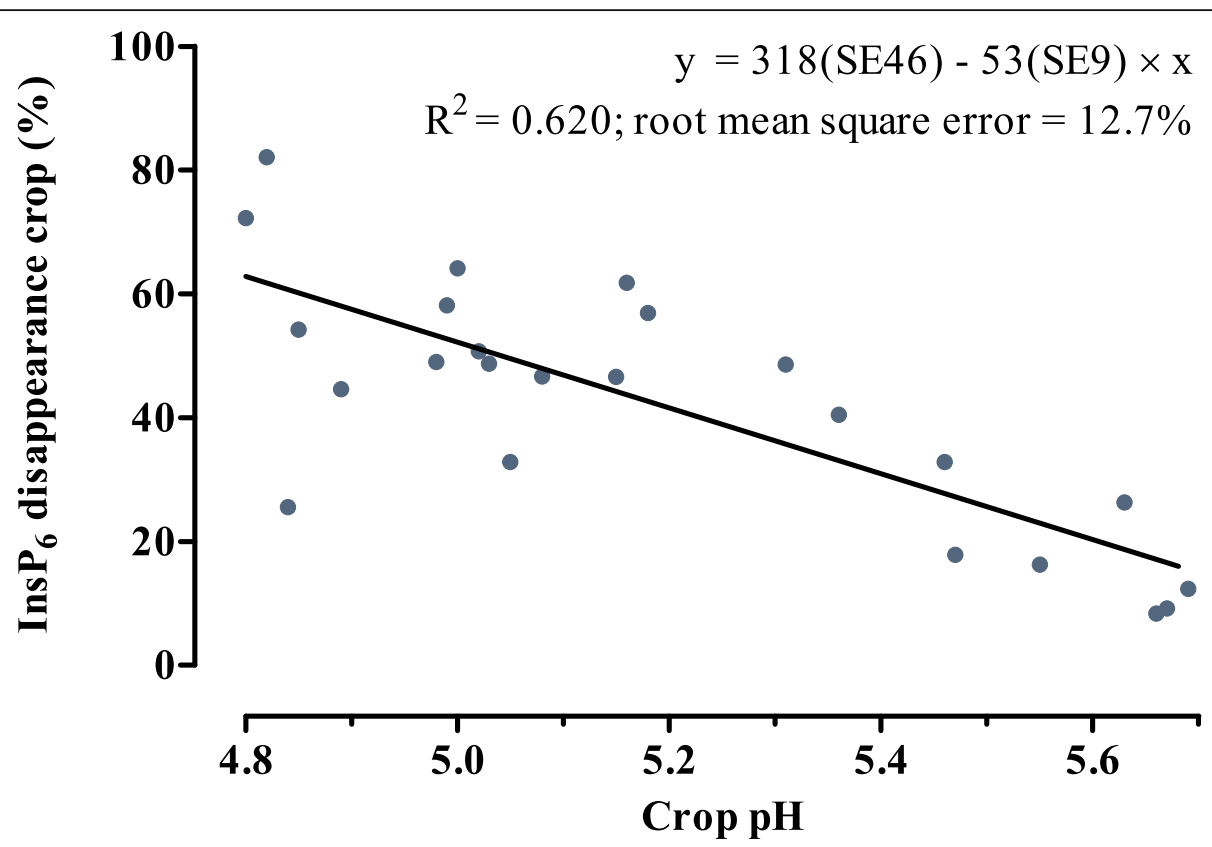

Fig. 9 Relationship between $\mathrm{pH}$ and $\mathrm{Ins}_{6}$ disappearance in the crop of broiler chickens fed diets with $\mathrm{CaCO}_{3}$ (without and with formic acid) at two dietary Ca levels with supplementation of $1500 \mathrm{FTU}$ phytase/kg. Dots represent observations corrected for block effects

formation and, hence, reduce $\mathrm{InsP}_{6}$ disappearance. $\mathrm{Ca}$ solubility of $\mathrm{Ca}$-formate was reported to be substantially higher than that of $\mathrm{CaCO}_{3}$ [23]. $\mathrm{InsP}_{6}$ disappearance in the crop was higher for $\mathrm{CaCO}_{3}$ compared to $\mathrm{Ca}$-formate, consistent with the theory of higher $\mathrm{Ca}$-Ins $\mathrm{P}_{6}$ complex formation as caused by higher solubility of Ca-formate. This is supported by the crop $\mathrm{pH}$ of 5.2 for Ca-formate and 5.5 for $\mathrm{CaCO}_{3}$, both being above the $\mathrm{pH}$ critical for complex formation [9]. As acidification can increase $\mathrm{Ca}$ solubility, $\mathrm{CaCO}_{3}+$ formic acid probably had higher $\mathrm{Ca}$ solubility than $\mathrm{CaCO}_{3}$ alone as a consequence of formic acid lowering the $\mathrm{pH}$ [24]. Formic acid supplementation would then make more $\mathrm{Ca}$ available for Ca-InsP $\mathrm{P}_{6}$ complex formation and thus reduce $\mathrm{InsP}_{6}$ disappearance. However, higher $\mathrm{InsP}_{6}$ disappearance in the crop was observed for $\mathrm{CaCO}_{3}+$ formic acid than for $\mathrm{CaCO}_{3}$. When $\mathrm{Ca}$-formate was used instead of $\mathrm{CaCO}_{3}$, InsP $\mathrm{P}_{6}$ disappearance in the crop was possibly determined more by the higher $\mathrm{Ca}-\mathrm{InsP}_{6}$ complex formation caused by higher Ca solubility than by the lower $\mathrm{pH}$. With formic acid supplementation, acidification may have had a higher impact on $\operatorname{InsP}_{6}$ degradation than the higher Ca solubility.

\section{lleum and gizzard}

\section{lleum microbiota and inositol phosphate degradation}

The reducing effect of the high $\mathrm{Ca}$ level on $\mathrm{pc} \mathrm{InsP}_{6}$ disappearance for $\mathrm{CaCO}_{3}$ but not for $\mathrm{CaCO}_{3}+$ formic acid may be caused by changes in endogenous phytase and other phosphatases produced by epithelial cells or by microbiota. The latter is supported by the effects of the dietary treatments on metabolic pathways of the microbial community connected to InsP $_{6}$ degradation. Changes in P-related metabolic pathways in the ileum were similar to those in the crop. The composition of the microbial community varied among treatments. ANOVA analyses of relative abundances of single OTUs revealed significant interactions for five OTUs $(1,5,7,8$, and 20; Table S5). However, an assessment of the contribution of these microorganisms to InsP degradation is difficult to derive because the phosphatase activity of the associated microorganisms is either not yet described in the literature or the OTUs define only classes of strains. Therefore, it cannot be estimated whether these microorganisms contributed phosphatase to a relevant extent. Nonetheless, results indicated that microorganisms in the digestive tract have contributed to $\mathrm{P}$ utilization of the birds. There were five positive correlations between pc P digestibility and OTUs assigned to $L$. reuteri and $L$. johnsonii; these microorganisms are known to produce phosphatase [17, 18]. Another possible explanation for differences in the microbial community could be an alteration of availability of nutrients for the microbiota in the digestive tract as a result of the varied supplements. To our knowledge, there is no literature available that supports or excludes one of these explanatory approaches. 


\section{Relation between calcium solubility, $\mathrm{pH}$, and inositol phosphate degradation}

High dietary Ca levels reduced $\mathrm{pc}$ Ins $\mathrm{P}_{6}$ degradation, but this effect was compensated by phytase supplementation. A decline in $\mathrm{pc}$ InsP $_{6}$ disappearance with graded levels of $\mathrm{CaCO}_{3}$ in diets for broiler chickens was previously described [3]. In the present study, effects of acidification, $\mathrm{Ca}$ level, and phytase supplementation on $\mathrm{InsP}_{6}$ degradation were interrelated. In contrast, $\mathrm{Li}$ et al. [7] and Dersjant-Li et al. [25] did not find an interaction between $\mathrm{CaCO}_{3}$ level and phytase supplementation on pc Ins $_{6}$ disappearance and $\mathrm{pc} P$ digestibility when up to 1000 and 500 phytase units (FTU) phytase/kg were supplemented, respectively. However, dietary Ca levels in these studies were higher than in the present study and a different phytase product with different features such as $\mathrm{pH}$ optimum was used. We are not aware of other studies on $\mathrm{InsP}_{6}$ degradation that compared $\mathrm{CaCO}_{3}$ with the more soluble Ca-formate. Hamdi et al. [4] determined no significant difference in pc $\mathrm{P}$ digestibility when $5.5 \mathrm{~g} \mathrm{Ca} / \mathrm{kg}$ was supplied by $\mathrm{CaCO}_{3}$ or the more soluble $\mathrm{Ca}$ chloride. In another series of experiments, $\mathrm{CaCO}_{3}$ was compared with a calcified marine seaweed considered a highly soluble Ca source [26-28]. Results of this series were not consistent, likely owing to different $\mathrm{Ca}$ and phytase supplementation levels. Further, comparisons between calcified marine seaweed and Ca sources investigated in these studies may be impeded by unknown substances contained in the seaweed products.
Overall, it seems that one major factor of $\mathrm{P}$ utilization affected by $\mathrm{Ca}$ sources and levels is the solubility of $\mathrm{Ca}$ from differing sources that depends, inter alia, on $\mathrm{pH}$ and microbiota. This supports conclusions drawn by Kim et al. [24] based on a comparison of $\mathrm{CaCO}_{3}$ sources.

Differences in pc InsP $\mathrm{P}_{6}$ disappearance between $\mathrm{CaCO}_{3}, \mathrm{CaCO}_{3}$ + formic acid, and $\mathrm{Ca}$-formate were smaller compared to $\mathrm{InsP}_{6}$ disappearance in the crop. A clear determination of pc InsP $_{6}$ disappearance as compared to $\operatorname{Ins}_{6}$ disappearance in the crop has been found in the present study, irrespective of whether phytase was supplemented or not (Fig. 10). This indicates the cleavage of $\mathrm{Ca}-\mathrm{InsP}_{6}$ complexes due to decreasing $\mathrm{pH}$ in the proventriculus and the gizzard. Gizzard $\mathrm{pH}$ ranged from 2.8-3.3, which was probably sufficient for cleavage of $\mathrm{Ca}-\mathrm{InsP}_{6}$ complexes because $\mathrm{Ca}-\mathrm{InsP}_{6}$ complexes occur at $\mathrm{pH} 4$ and higher [29].

No difference in $\mathrm{pc}$ InsP $_{6}$ disappearance was found between $\mathrm{CaCO}_{3}$ + formic acid at both $\mathrm{Ca}$ levels and the lower $\mathrm{Ca}$ level of $\mathrm{CaCO}_{3}$. A reason for this could be the higher efficacy of phytase caused by a decreased crop $\mathrm{pH}$ and less complete $\mathrm{InsP}_{6}$ degradation for Ca-formate due to higher $\mathrm{Ca}$ solubility. We are not aware of other studies investigating a simultaneous supplementation of formic acid and phytase in poultry. However, in pigs, total tract $\mathrm{P}$ digestibility was increased to a higher extent when phytase and

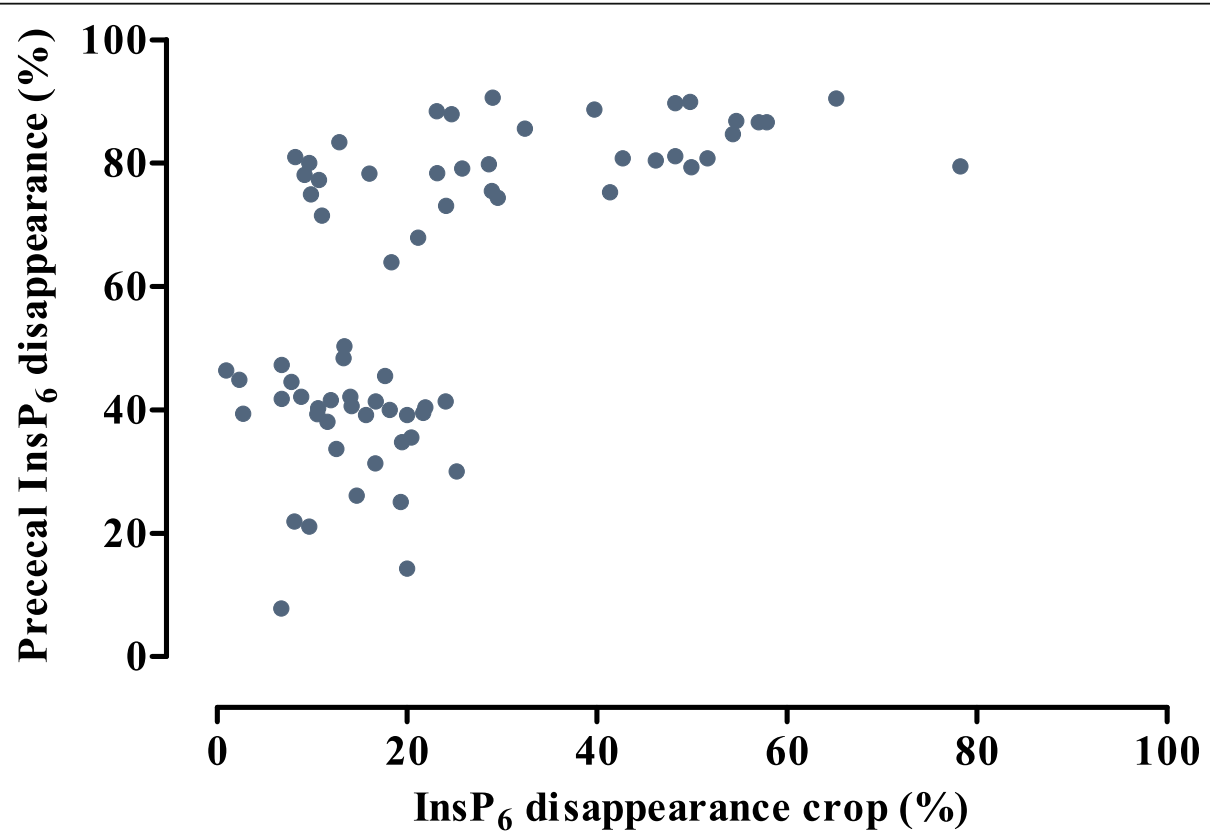

Fig. 10 Relationship between $\mathrm{Ins}_{6}$ disappearance in the crop and prececal Ins $\mathrm{P}_{6}$ disappearance of broiler chickens. Dots represent observations corrected for block effects without (below 60\% prececal InsP6 disappearance) or with (above $60 \%$ prececal InsP 6 disappearance) supplementation of $1500 \mathrm{FTU}$ phytase/kg 
formic acid were supplemented together than when their separate effects were summed [30].

\section{Effects on inositol phosphate degradation pathways}

Concentrations of lower InsP isomers in gastrointestinal content give insights into effects on InsP degradation pathways, including limiting steps in the process of InsP degradation. InsP isomers that limit InsP degradation apparently differed among treatments. When no phytase was supplemented, InsP degradation by endogenous enzymes seems to have been limited by the high $\mathrm{Ca}$ level. High $\mathrm{Ca}$ supposedly inhibited the activity of endogenous enzymes at different stages of the degradation pathway of InsP $\mathrm{P}_{6}$ and lower InsP isomers depending on the Ca source. This interpretation is based on lower concentrations of myo-inositol and higher concentrations of InsP $_{6}$ and $\mathrm{InsP}_{5}$ isomers in the ileum at the high compared to the low $\mathrm{Ca}$ level of the $\mathrm{CaCO}_{3}$ and $\mathrm{Ca}$-formate treatments. In the $\mathrm{CaCO}_{3}+$ formic acid treatment, there was no difference in $\mathrm{InsP}_{6}$ concentrations in the ileum between the Ca levels, but there was slightly higher $\mathrm{InsP}_{5}$ isomer and lower myo-inositol concentrations at the high Ca level. Obviously, formic acid supplementation overcame a restricted release of the first phosphate group from $\operatorname{Ins}_{6}$ at the high $\mathrm{Ca}$ level that was observed in the $\mathrm{CaCO}_{3}$ and $\mathrm{Ca}$-formate treatments.

Degradation of lower InsP isomers in the ileum seems to be impaired by the high $\mathrm{Ca}$ level when phytase was supplemented. In the $\mathrm{CaCO}_{3}$ treatment, higher $\mathrm{InsP}_{4}$ and $\mathrm{InsP}_{3}$ isomer concentrations and lower myo-inositol concentrations were found for the high compared to the low $\mathrm{Ca}$ level. This suggests a diminishing effect of a higher $\mathrm{Ca}$ level on phosphatases degrading $\mathrm{InsP}_{4}$ and lower InsP isomers. Similar InsP $\mathrm{P}_{3}$ to $\mathrm{InsP}_{6}$ concentrations were determined between the low $\mathrm{Ca}$ level of the $\mathrm{CaCO}_{3}$ and the $\mathrm{CaCO}_{3}$ + formic acid treatments, but higher myo-inositol concentrations were determined for the $\mathrm{CaCO}_{3}+$ formic acid treatment. This may indicate a higher or faster hydrolysis of $\operatorname{InsP}_{2}$ and $\mathrm{InsP}_{1}$ isomers for the $\mathrm{CaCO}_{3}+$ formic acid treatment at the low $\mathrm{Ca}$ level. A fast degradation of InsP $\mathrm{P}_{2}$ and $\mathrm{InsP}_{1}$ isomers by the use of formic acid could also be observed in the higher $\mathrm{Ca}$ level. At high Ca levels, higher InsP $\mathrm{P}_{5}$ to $\mathrm{InsP}_{3}$ concentrations were found for the $\mathrm{CaCO}_{3}+$ formic acid treatment compared to the $\mathrm{CaCO}_{3}$ treatment, but there was no difference in myo-inositol concentration. Despite a slower degradation of $\operatorname{InsP}_{5}$ to InsP $_{3}$ isomers, this points towards a high hydrolysis of Ins $\mathrm{P}_{2}$ and InsP $_{1}$ isomers for the high $\mathrm{Ca}$ level for $\mathrm{CaCO}_{3}+$ formic acid. However, it should be of greater interest to degrade InsP with higher phosphorylation first so as to diminish potential chelating effects. Comparing the low $\mathrm{Ca}$ levels in the $\mathrm{CaCO}_{3}$ and $\mathrm{Ca}$-formate treatments, higher concentrations of
$\mathrm{InsP}_{6}$ and $\mathrm{InsP}_{5}$ isomers and similar myo-inositol concentrations were found, indicating that the initial steps of Ins $\mathrm{P}_{6}$ degradation were impeded for Ca-formate, and degradation of InsP isomers lower than $\mathrm{InsP}_{5}$ was not the limiting factor. Degradation of $\operatorname{InsP}_{2}$ and $\mathrm{InsP}_{1}$ isomers seems to be particularly relevant for InsP degradation at both $\mathrm{Ca}$ levels for $\mathrm{CaCO}_{3}+$ formic acid when phytase was supplemented. This makes the knowledge of $\operatorname{InsP}_{2}$ and $\mathrm{InsP}_{1}$ isomer concentrations necessary so as to determine InsP isomers that limit InsP degradation.

\section{Effects on calcium digestibility}

Responses in pc Ca digestibility differed from other traits under investigation, probably as a result of highly regulated $\mathrm{Ca}$ homeostasis and regulation of $\mathrm{Ca}$ absorption [31]. Phytase supplementation increased the pc digested amount of $\mathrm{Ca}$ irrespective of acidification at the low $\mathrm{Ca}$ level, whereas such an effect was only observed for $\mathrm{Ca}$ formate at the high Ca level. This may be explained by a maximum pc digested $\mathrm{Ca}$ amount of about $0.42 \mathrm{~g} / \mathrm{d}$. This amount was met at the high $\mathrm{Ca}$ level without phytase supplementation for $\mathrm{CaCO}_{3}$ and $\mathrm{CaCO}_{3}$ + formic acid, but for Ca-formate only when phytase was supplemented. Particle size [28, 32] and Ca solubility [24] of $\mathrm{Ca}$ sources were shown to be a determinant of $\mathrm{Ca}$ utilization. Possibly, the considerably higher mean particle size of Ca-formate compared to $\mathrm{CaCO}_{3}$ was more limiting for $\mathrm{Ca}$ utilization than the higher solubility of Ca-formate.

\section{Conclusions}

Replacing $\mathrm{CaCO}_{3}$ by $\mathrm{Ca}$-formate and adding formic acid to $\mathrm{CaCO}_{3}$-containing diets decreased digesta $\mathrm{pH}$, influenced the microbial community, and had an effect on Ins $_{6}$ degradation. Results imply that InsP degradation in the crop and until the terminal ileum may partly be explained by the microbial community because relationships between InsP degradation and relative abundance of phosphatase-producing strains $L$. johnsonii and L. reuteri were observed. Functional prediction also suggested influences of the microbiota on InsP degradation. In addition to microbiota, $\mathrm{Ca}$ effects on InsP degradation and pc $\mathrm{P}$ digestibility were shown to depend on dietary concentration, solubility of the Ca sources, as well as on the consequences of $\mathrm{Ca}$ supply on the $\mathrm{pH}$ of the digestive tract. The results of this study are relevant to the industry because choice of concentration and source of $\mathrm{Ca}$ in the diet is an important factor of feed formulation that affects $\mathrm{P}$ utilization by the animals.

\section{Methods}

Animals and management

The experiment was conducted at the Agriculture Experiment Station of the University of Hohenheim. 
Unsexed Ross 308 broilers were obtained from a commercial hatchery (Brüterei Süd ZN der BWEBrüterei Weser-Ems GmbH \& Co. KG, Regenstauf, Germany). The hatchlings were placed in 72 floor pens $(115 \times 230 \mathrm{~cm}$ ground area, $260 \mathrm{~cm}$ height $)$ in groups of 15 . The temperature was gradually reduced from $34{ }^{\circ} \mathrm{C}$ at placement to $26^{\circ} \mathrm{C}$ at the end of the experiment on day 22 . The light regimen was 24:0 $\mathrm{h}$ of light:dark in the first three days and 18:6 h of light:dark from day 4 until the end of the experiment. Birds were kept on wood shavings for the first 15 days. On day 16, the litter was removed from the floor and birds were kept on perforated floors thereafter. Birds were reallocated among pens on day 16 to achieve a similar group weight in all pens. The pens were randomly assigned to the treatments in a completely randomized block design. Feed and water were available for ad libitum consumption throughout the experiment.

\section{Diets}

A commercial starter diet was provided for the first 15 days and contained, per $\mathrm{kg}, 215 \mathrm{~g}$ crude protein, $11 \mathrm{~g} \mathrm{Ca}$, $7 \mathrm{~g}$ P, $12.5 \mathrm{MJ}$ metabolizable energy, $110 \mathrm{mg}$ monensin sodium, 10 IU endo-1,4- $\beta$-xylanase, and 750 FTU of a 6 phytase (Deutsche Tiernahrung Cremer $\mathrm{GmbH} \& \mathrm{Co}$. KG, Düsseldorf, Germany). From day 16, the experimental diets were provided.

Twelve experimental diets were mixed (Table S14). Except for $\mathrm{Ca}$ and $\mathrm{P}$, the diets were calculated to meet or exceed the supply recommendations of the Gesellschaft für Ernährungsphysiologie [33]. The diets were based on corn, soybean meal, rapeseed meal, and sunflower meal and were formulated without mineral $P$. High levels of oilseed meals were included to achieve high $\mathrm{InsP}_{6}$ concentrations as a substrate for the added phytase. Titanium dioxide was included as an indigestible marker at a level of $5 \mathrm{~g} / \mathrm{kg}$. Diets contained $\mathrm{CaCO}_{3}$, $\mathrm{CaCO}_{3}+$ formic acid $(6 \mathrm{~g} / \mathrm{kg}$; Amasil 85 , BASF SE, Germany; $>85 \% \mathrm{wt} / \mathrm{wt}$ formic acid), or Ca-formate. $\mathrm{CaCO}_{3}$ and $\mathrm{Ca}$-formate were added in two concentrations in order to achieve dietary Ca levels of $5.6 \mathrm{~g} \mathrm{Ca} / \mathrm{kg}$ dry matter ("low") or $8.2 \mathrm{~g} \mathrm{Ca} / \mathrm{kg}$ dry matter ("high"). One half of each diet was supplemented with 1500 FTU phytase/kg ("+"; Natuphos E 5000 G, BASF SE, Germany). The other half remained without phytase supplement ("-"). Diamol (diatomaceous earth) was used to balance mass differences between diets. Overall, analyzed nutrient concentrations confirmed calculated values (Table S15). The diets were produced by Research Diet Services (Research Diet Services BV, Hoge Maat 10, 3961NC, Wijk bij Duurstede, Netherlands) and pelleted through a 3-mm die.

\section{Measurements and sampling procedures}

Animals and feed were weighed on day 16 and at the end of the experimental period on a pen basis. At the end of the experiment, half of the pens of each treatment were processed on day 21 and day 22, respectively, for capacity reasons. The animals were deprived of feed $2 \mathrm{~h}$ before slaughter, and, feeders were moved back into the pens $1 \mathrm{~h}$ before slaughter in order to standardize gut fill. The animals were stunned using a gas mixture (35\% $\mathrm{CO}_{2}, 35 \% \mathrm{~N}_{2}$, and $30 \% \mathrm{O}_{2}$ ) and euthanized by $\mathrm{CO}_{2}$ exposure. Crop and gizzard content was removed with a spatula without scraping the mucosa and pooled on a pen basis. A subsample of the pooled crop digesta was used for microbiota analysis and $\mathrm{pH}$ measurement. The section between Meckel's diverticulum and $2 \mathrm{~cm}$ anterior to the ileo-ceco-colonic junction, herein defined as the ileum, was removed. Digesta from the posterior half of the ileum was sampled because $\mathrm{P}$ absorption in the anterior third of the ileum may not have been completed [34]. Approximately $2 \mathrm{~cm}$ of this ileum section was used for $\mathrm{pH}$ and microbiota analysis. For this purpose, the digesta was carefully stripped out. Samples for microbiota analyses were immediately stored at $-20^{\circ} \mathrm{C}$. The digesta of the remainder of this ileum section was flushed out using ice-cold deionized water and pooled on a pen basis. Digesta samples were immediately frozen at $-20^{\circ} \mathrm{C}$ until they were freeze-dried.

\section{Microbial community analyses}

DNA from crop and ileum digesta samples were extracted with the commercial DNA extraction kit FastDNA $^{\text {ma }}$ Spin Kit for soil (MP Biomedicals LLC, Solon, $\mathrm{OH}$, USA). DNA was further quantified with a NanoDrop 2000 spectrophotometer (Thermo Fisher Scientific, MA, USA) and stored at $-20^{\circ} \mathrm{C}$. Illumina library was prepared according to Kaewtapee et al. [35]. The V1-2 region of the $16 \mathrm{~S}$ rRNA gene was amplified and $1 \mu \mathrm{l}$ of the first polymerase-chain reaction (PCR) product was used as a template in the second PCR with multiplexing and indexing primers as described previously [36]. Samples were sent for pair-end sequencing using the $250 \mathrm{bp}$ paired-end sequencing chemistry on an Illumina MiSeq platform. Raw reads were checked for quality, assembled, and aligned using the mothur pipeline tool [37]. The data included 74,662 \pm 3399 sequences per sample. The UCHIME program included in the mothur pipeline was used to identify possible chimeras [38]. Reads were clustered at $97 \%$ identity into 681 OTUs. Only OTUs with an average abundance higher than $0.0001 \%$ and a sequence longer than $250 \mathrm{bp}$ were considered for further analysis. The closest representative was manually identified using seqmatch from the Ribosomal Database Project [39]. Sequences were submitted to European 
Nucleotide Archive under the accession number PRJEB38378.

Prediction of functionality was carried out with the $\mathrm{R}$ package Tax4Fun2 [40], which relied on the SILVA database [41] and used the KEGG hierarchy, comprising of gene catalogs from sequenced genomes [42], for the assignations. To assign functionality, the BIOM table was obtained from the mothur pipeline [43]. Genomes from 16S rRNA gene sequences identified in this study were downloaded from the NCBI database (https://www. ncbi.nlm.nih.gov/home/genomes/) in order to produce a database specially made for the crop and ileum of chickens.

\section{Chemical and physical analyses}

Samples of all diets were pulverized using a vibrating cup mill (Pulverisette 9, Fritsch GmbH, Idar-Oberstein, Germany) for chemical analyses of gross energy, P, Ca, $\mathrm{Ti}$, InsP isomers, and myo-inositol, or ground to pass through a $0.5 \mathrm{~mm}$ sieve (Ultra Centrifugal Mill ZM 200, Retsch GmbH, Haan, Germany) for all other analyses. Digesta samples were pulverized using the same vibrating cup mill. Ground samples were analyzed for proximate nutrients and fiber fractions according to the methods of Verband Deutscher Landwirtschaftlicher Untersuchungs- und Forschungsanstalten [44]. The concentrations of $\mathrm{Ti}, \mathrm{P}$, and $\mathrm{Ca}$ in pulverized feed and digesta samples were analyzed using inductively coupled plasma-optical emission spectrometry following wet digestion [45]. Ins $\mathrm{P}_{6}$ and InsP $\mathrm{P}_{3-5}$ isomers were analyzed in pulverized feed and digesta samples according to methods described by Zeller et al. [45] with modifications noted by Sommerfeld et al. [1]. Separation of enantiomers is not possible using this methodology; therefore, we were unable to distinguish between the Dand $\mathrm{L}$-forms. Some InsP $\mathrm{P}_{3}$ isomers could not be identified because standards were unavailable. Clear discrimination of the isomers Ins $(1,2,6) \mathrm{P}_{3}$, Ins $(1,4,5) \mathrm{P}_{3}$, and Ins $(2,4$, 5) $P_{3}$ was not possible because they co-eluted, and therefore the term InsP $\mathrm{P}_{3 \mathrm{x}}$ was used for these $\mathrm{InsP}_{3}$ isomers of unknown proportions. Myo-inositol in feed and digesta samples was analyzed according to Sommerfeld et al. [46], using gas chromatography/mass spectrometry following derivatization. Phytase activity of the diets was analyzed according to an ISO standard method [47]. Measurements of $\mathrm{pH}$ in the undiluted content of the digestive tract were done using a CG 840 digital pH meter (Schott-Geräte GmbH, Mainz, Germany) equipped with a temperature probe and a puncture solid-state $\mathrm{pH}$ electrode suitable for semi-solid samples (InLab Solids Pro-ISM, Mettler Toledo Inc., Columbus, USA) as described previously [48].

Particle size distribution of $\mathrm{CaCO}_{3}$ and $\mathrm{Ca}$-formate were analyzed at Forschungsinstitut Futtermitteltechnik
e.V. Braunschweig, Germany by laser diffraction (Sensor: HELOS Hi202, measuring range: 0.5/0.9-175 $\mu \mathrm{m}$, dispersing system: Rodos/L (402F); SYMPATEC, ClausthalZellerfeld). Particle sizes of the diets were measured as described by Grubješić et al. [49] by wet sieving analysis using a sieve shaker (AS200, Retsch GmbH, Germany) with sieve sizes of $2,1.18,1,0.5,0.25,0.125$, and 0.063 $\mathrm{mm}$.

\section{Calculations and statistics}

The ADG, ADFI, and G:F were calculated on a pen basis from day 16 to the end of the experiment and corrected for mortality. Prececal $\mathrm{InsP}_{6}$ disappearance and $\mathrm{pc}$ digestibility of $\mathrm{P}$ and $\mathrm{Ca}(\mathrm{y})$ were calculated on a pen basis using the following equation:

$$
\begin{aligned}
\mathrm{y}(\%)= & 100-100 \\
& \times\left(\frac{\mathrm{TiO}_{2} \text { infeed }(\mathrm{g} / \mathrm{kg} \text { drymatter })}{\mathrm{TiO}_{2} \text { indigesta }(\mathrm{g} / \mathrm{kg} \text { drymatter })}\right. \\
& \left.\times \frac{\text { Analyteindigesta }(\mathrm{g} / \text { kgdrymatter })}{\text { Analyteinfeed }(\mathrm{g} / \mathrm{kgdrymatter})}\right)
\end{aligned}
$$

Statistical evaluation of all traits was performed according to the following model:

$$
\begin{aligned}
\mathrm{y}_{i j k l}= & \mu+\text { Acidification }_{i}+\text { Calevel }_{j}+\text { Phytase }_{k} \\
& +\left(\text { Acidification }_{i} \times \text { Calevel }_{j}\right) \\
& +\left(\text { Acidification }_{i} \times \text { Phytase }_{k}\right) \\
& +\left(\text { Calevel }_{j} \times \text { Phytase }_{k}\right) \\
& +\left(\text { Acidification }_{i} \times \text { Calevel }_{j} \times \text { Phytase }_{k}\right) \\
& + \text { block }_{l}+\mathrm{e}_{i j k l}
\end{aligned}
$$

where $y_{i j k l}$ is the mean value of each treatment; $\mu$ is the mean of all treatments; Acidification ${ }_{i}$ is the fixed effect of diets containing $\mathrm{CaCO}_{3}, \mathrm{CaCO}_{3}+$ formic acid, or Ca-formate; $\mathrm{Ca}$ level $_{j}$ is the fixed effect of the Ca level (5.6 or $8.2 \mathrm{~g} / \mathrm{kg}$ dry matter); Phytase $_{k}$ is the fixed effect of phytase supplementation (0 or 1500 FTU phytase $/ \mathrm{kg}$ ); block $_{l}$ is the random block effect; and $\mathrm{e}_{i j k l}$ is the residual error. The block effect included possible effects of location in the building and sampling time on day 21 or day 22 because three blocks were sampled each day. ANOVA was calculated using the MIXED procedure of the SAS for Windows (version 9.4, SAS Institute, Cary, NC, USA). Normal distribution and homogeneity of variance were tested prior to statistical analysis. $P$ values described herein result from ANOVA, or $t$ tests when two groups were compared.

In order to describe the particle size distribution of the diets, the equation described by Siegert et al. [50] was fitted to the results of the sieve analysis using the NLMIXED procedure of SAS:

$$
y=\frac{100}{1+e^{(-a \times(x-b))}}
$$


where $y$ is the cumulative percentage of particles smaller than the sieve size $x(\mathrm{~mm})$, $a$ is the slope of the regression, and $b$ is the inflection point, which can be interpreted as the mean particle size ( $\mathrm{mm}$ ).

The sequencing dataset was statistically analyzed as described by Borda-Molina et al. [51] using the PRIMER software (PRIMER-E, version 7.0.9, Plymouth Marine Laboratory, Plymouth, UK) [52]. The dataset was first standardized by the total, then comparisons between samples were made through a sample similarity matrix using the Bray-Curtis coefficient algorithm. A hierarchical cluster analysis was done to show the similarity between samples. PERMANOVA was used to compare the microbial community among the treatments and between the sections (PRIMER-E, version 7.0.9, Plymouth Marine Laboratory, Plymouth, UK). The similarity percentage analysis (SIMP ER) identified the OTU contribution to the similarity among samples within each treatment. Differences in the relative abundance of single OTUs were also estimated based on eq. 2. Pearson correlations with other traits were calculated for OTUs with a relative abundance $>1 \%$ using GraphPad Prism 5 (GraphPad Software Inc., San Diego, CA, USA). Significance was declared at $P \leq 0.050$ for all statistical analyses.

\section{Abbreviations}

ADFI: Average daily feed intake; ADG: Average daily gain; ANOVA: Analysis of variance; Ca: Calcium; $\mathrm{CaCO}_{3}$ : Calcium carbonate; FTU: Phytase units;

G:F: Gain to feed ratio; InsP: Inositol phosphate; InsP 6 : myo-inositol 1,2,3,4,5,6hexakis (dihydrogen phosphate); OTU: Operative taxonomic units;

P: Phosphorus; pc: Prececal; PCR: Polymerase-chain; PERM

ANOVA: Permutational multivariate analysis of variance; pp.: Percentage point; SIMPER: Similarity percentage analysis

\section{Supplementary Information}

The online version contains supplementary material available at https:/doi. org/10.1186/s42523-021-00083-7.

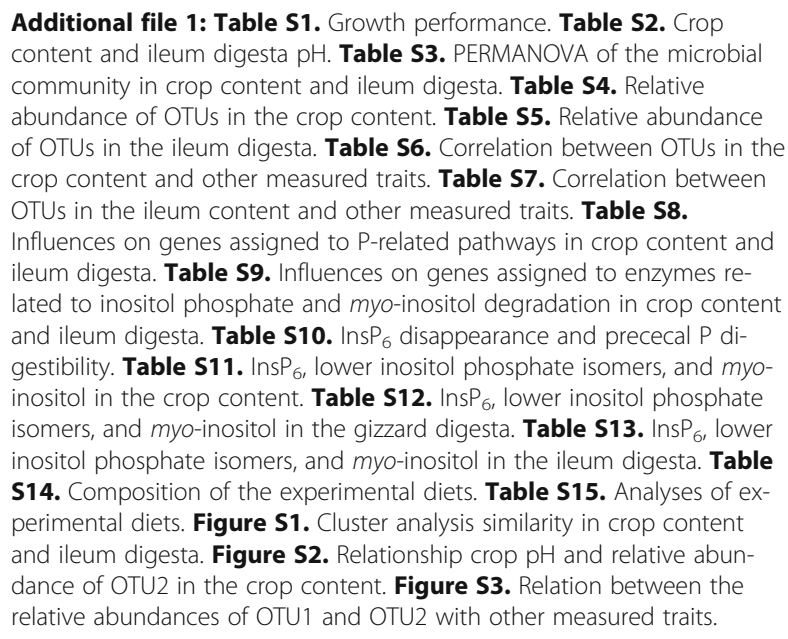

\section{Acknowledgements}

The authors acknowledge support by the High Performance and Cloud Computing Group at the Zentrum für Datenverarbeitung of the University of
Tübingen, the state of Baden-Württemberg through bwHPC and the German Research Foundation (DFG) through grant no INST 37/935-1 FUGG. The support of Melanie Liebscher, Helga Ott, and Margit Schollenberger in conducting chemical analyses and of Heiko Stegmann, Jan Abegg, and Artur Freudigmann for taking care of the animals at the experimental station is gratefully acknowledged.

\section{Further information}

Presented in part in: Krieg J, Chi YP, Feuerstein D, Siegert W, Rodehutscord M. Effect of dietary Ca concentration on precaecal Ins $\mathrm{P}_{6}$ disappearance and $\mathrm{P}$ digestibility in broiler chickens depends on the Ca source. Proc Soc Nutr Phys 2020;29:64 and Borda-Molina D, Krieg J, Feuerstein D, Rodehutscord M, Camarinha-Silva A. Microbial changes in the crop and the ileum under the influence of dietary Ca supplementation in broiler chickens. Proc Soc Nutr Phys 2020;29:65

\section{Authors' contributions}

JK, WS, VS, DF, and MR conceived and designed the experiment; JK, WS, DBM, VS, YPC, and HRT performed the experiments; JK, WS, and YPC conducted the animal data analysis; DBM, JK, WS, and ACS performed the microbial data analysis; JK, WS, and DBM conducted the statistical analysis; JK, WS, VS, and DBM drafted the paper; all authors revised the paper and approve of the final draft.

\section{Authors' information}

${ }^{1}$ Institute of Animal Science, University of Hohenheim, 70599 Stuttgart, Germany. ${ }^{3}$ BASF SE, 68623 Lampertheim, Germany.

\section{Funding}

This study was financially supported by BASF SE, Ludwigshafen. All authors declare that the funding source had no influence on this study, including on its study design, analysis of results, and interpretations. Open Access funding enabled and organized by Projekt DEAL.

\section{Availability of data and materials}

All data generated or analyzed during this study are included in this published article and its supplementary information files.

\section{Ethics approval and consent to participate}

The experiment was conducted in accordance with German Animal Welfare Legislation following approval of the Regierungspräsidium Tübingen, Germany (approval no. HOH53-18TE).

\section{Consent for publication}

Not applicable.

\section{Competing interests}

DF is an employee of BASF SE. The authors declare that they have no competing interests.

\section{Author details}

${ }^{1}$ Institute of Animal Science, University of Hohenheim, 70599 Stuttgart, Germany. ${ }^{2}$ Department of Animal Science, Faculty of Agriculture, University of Zanjan, Zanjan 45371-38791, Iran. ${ }^{3}$ BASF SE, 68623 Lampertheim, Germany.

Received: 10 August 2020 Accepted: 8 February 2021

Published online: 15 March 2021

\section{References}

1. Sommerfeld V, Schollenberger M, Kühn I, Rodehutscord M. Interactive effects of phosphorus, calcium, and phytase supplements on products of phytate degradation in the digestive tract of broiler chickens. Poult Sci. 2018;97:1177-88. https://doi.org/10.3382/ps/pex404.

2. Selle $\mathrm{PH}$, Cowieson AJ, Ravindran V. Consequences of calcium interactions with phytate and phytase for poultry and pigs. Livest Sci. 2009;124:126-41. https://doi.org/10.1016/j.livsci.2009.01.006.

3. Plumstead PW, Leytem AB, Maguire RO, Spears JW, Kwanyuen P, Brake J. Interaction of calcium and phytate in broiler diets. 1. Effects on apparent prececal digestibility and retention of phosphorus. Poult Sci. 2008;87:44958. https://doi.org/10.3382/ps.2007-00231. 
4. Hamdi M, Solà-Oriol D, Davin R, Perez JF. Calcium sources and their interaction with the different levels of non-phytate phosphorus affect performance and bone mineralization in broiler chickens. Poult Sci. 2015;94: 2136-43. https://doi.org/10.3382/ps/peu061.

5. Xing $R$, Yang $H$, Wang $X, Y u H$, Liu S, Li P. Effects of calcium source and calcium level on growth performance, immune organ indexes, serum components, intestinal microbiota, and intestinal morphology of broiler chickens. J Appl Poult Res. 2020;29:106-20. https://doi.org/10.3382/japr/ pfz033.

6. Angel R, Tamim NM, Applegate TJ, Dhandu AS, Ellestad LE. Phytic acid chemistry: influence on phytin-phosphorus availability and phytase efficacy. J Appl Poult Res. 2002;11:471-80. https://doi.org/10.1093/japr/11.4.471

7. Li W, Angel R, Kim S-W, Jiménez-Moreno E, Proszkowiec-Weglarz M, Plumstead PW. Impacts of age and calcium on phytase efficacy in broiler chickens. Anim Feed Sci Tech. 2018;238:9-17. https://doi.org/10.1016/j.a nifeedsci.2018.01.021.

8. Lawlor PG, Lynch PB, Caffrey PJ, O'Reilly JJ, O'Connell MK. Measurements of the acid-binding capacity of ingredients used in pig diets. Ir Vet J. 2005;58: 447-52. https://doi.org/10.1186/2046-0481-58-8-447.

9. Grynspan F, Cheryan M. Calcium phytate: effect of $\mathrm{pH}$ and molar ratio on in vitro solubility. J Am Oil Chem Soc. 1983;60:1761-4. https://doi.org/10.1 007/BF02680350.

10. Kim JW, Kim JH, Kil DY. Dietary organic acids for broiler chickens. A review. Rev Colomb Cienc Pecu. 2015;28:109-23. https://doi.org/10.17533/udea.rccp. $\mathrm{v} 28 \mathrm{n} 2 \mathrm{a} 01$.

11. van Immerseel F, Russell JB, Flythe MD, Gantois I, Timbermont L, Pasmans F, et al. The use of organic acids to combat Salmonella in poultry. A mechanistic explanation of the efficacy. Avian Pathol. 2006;35:182-8. https:// doi.org/10.1080/03079450600711045.

12. Theron MM, Lues JR. Organic acids and food preservation. Boca Raton, Fl: CRC Press; 2019

13. Dibner JJ, Buttin P. Use of organic acids as a model to study the impact of gut microflora on nutrition and metabolism. J Appl Poult Res. 2002;11:45363. https://doi.org/10.1093/japr/11.4.453.

14. Toplaghaltsyan A, Bazukyan I, Trchounian A. The effects of different carbon sources on the antifungal activity by lactic acid bacteria. Curr Microbiol. 2017;74:168-74. https://doi.org/10.1007/s00284-016-1168-8.

15. van Immerseel F, Fievez V, de Buck J, Pasmans F, Martel A, Haesebrouck F, Ducatelle R. Poult Sci. 2004;83:69-74. https://doi.org/10.1093/ps/83.1.69.

16. Bang J, Lee SY. Assimilation of formic acid and $\mathrm{CO}_{2}$ by engineered Escherichia coli equipped with reconstructed one-carbon assimilation pathways. Proc Natl Acad Sci U S A. 2018;115:E9271-9. https://doi.org/10.1 073/pnas.1810386115.

17. Neveling DP, Ahire JJ, Laubscher W, Rautenbach M, Dicks LMT. Genetic and phenotypic characteristics of a multi-strain probiotic for broilers. Curr Microbiol. 2020;77:369-87. https://doi.org/10.1007/s00284-019-01797-3.

18. Hayek SA, Shahbazi A, Worku M, Ibrahim SA. Enzymatic activity of Lactobacillus reuteri grown in a sweet potato based medium with the addition of metal ions. Springerplus. 2013;2:465. https://doi.org/10.1186/2193-1801-2-465.

19. Davoren MJ, Liu J, Castellanos J, Rodríguez-Malavé NI, Schiestl RH. A novel probiotic, Lactobacillus johnsonii 456, resists acid and can persist in the human gut beyond the initial ingestion period. Gut Microbes. 2019;10:45880. https://doi.org/10.1080/19490976.2018.1547612.

20. Wang H, Ni X, Qing X, Liu L, Xin J, Luo M, et al. Probiotic Lactobacillus johnsonii BS15 improves blood parameters related to immunity in broilers experimentally infected with subclinical necrotic enteritis. Front Microbiol. 2018;9:49. https://doi.org/10.3389/fmicb.2018.00049.

21. Kumar V, Yadav AN, Verma P, Sangwan P, Saxena A, Kumar K, Singh B. BPropeller phytases: diversity, catalytic attributes, current developments and potential biotechnological applications. Int J Biol Macromol. 2017;98:595609. https://doi.org/10.1016/j.ijbiomac.2017.01.134.

22. Shin $\mathrm{S}, \mathrm{Ha} \mathrm{N}-\mathrm{C}$, Oh B-C, Oh T-K, Oh B-H. Enzyme mechanism and catalytic property of $\beta$ propeller phytase. Structure. 2001;9:851-8. https://doi.org/10.1 016/s0969-2126(01)00637-2.

23. Burns DA, Ciurczak EW, editors. Handbook of near-infrared analysis. 3rd ed. Boca Raton: CRC Press; 2008.

24. Kim S-W, Li W, Angel R, Plumstead PW. Modification of a limestone solubility method and potential to correlate with in vivo limestone calcium digestibility. Poult Sci. 2019;98:6837-48. https://doi.org/10.3382/ps/pez423.

25. Dersjant-Li Y, Evans C, Kumar A. Effect of phytase dose and reduction in dietary calcium on performance, nutrient digestibility, bone ash and mineralization in broilers fed corn-soybean meal-based diets with reduced nutrient density. Anim Feed Sci Tech. 2018;242:95-110. https://doi.org/10.1 016/j.anifeedsci.2018.05.013.

26. Paiva DM, Walk CL, McElroy AP. Influence of dietary calcium level, calcium source, and phytase on bird performance and mineral digestibility during a natural necrotic enteritis episode. Poult Sci. 2013;92:3125-33. https://doi. org/10.3382/ps.2013-03298

27. Bradbury EJ, Wilkinson SJ, Cronin GM, Thomson P, Walk CL, Cowieson AJ. Evaluation of the effect of a highly soluble calcium source in broiler diets supplemented with phytase on performance, nutrient digestibility, foot ash, mobility and leg weakness. Anim Prod Sci. 2017;57:2016. https://doi.org/10.1 071/AN16142.

28. Bradbury EJ, Wilkinson SJ, Cronin GM, Walk CL, Cowieson AJ. Effects of phytase, calcium source, calcium concentration and particle size on broiler performance, nutrient digestibility and skeletal integrity. Anim Prod Sci. 2018;58:271. https://doi.org/10.1071/AN16175.

29. Wise A, Gilburt DJ. Binding of cadmium and lead to the calcium-phytate complex in vitro. Toxicol Lett. 1981;9:45-50. https://doi.org/10.1016/0378-42 74(81)90173-9.

30. Jongbloed AW, Mroz Z, van der Weij-Jongbloed R, Kemme PA. The effects of microbial phytase, organic acids and their interaction in diets for growing pigs. Livest Prod Sci. 2000;67:113-22. https://doi.org/10.1016/S0301-622 6(00)00179-2.

31. Proszkowiec-Weglarz M, Angel R. Calcium and phosphorus metabolism in broilers: effect of homeostatic mechanism on calcium and phosphorus digestibility. J Appl Poult Res. 2013;22:609-27. https://doi.org/10.3382/japr.2 012-00743.

32. Guinotte F, Nys Y, de Monredon F. The effects of particle size and origin of calcium carbonate on performance and ossification characteristics in broiler chicks. Poult Sci. 1991;70:1908-20. https://doi.org/10.3382/ps.0701908.

33. Gesellschaft für Ernährungsphysiologie. Empfehlungen zur Energie- und Nährstoffversorgung der Legehennen und Masthühner (Broiler). Frankfurt am Main: DLG-Verlag; 1999.

34. Rodehutscord M, Dieckmann A, Witzig M, Shastak Y. A note on sampling digesta from the ileum of broilers in phosphorus digestibility studies. Poult Sci. 2012;91:965-71. https://doi.org/10.3382/ps.2011-01943.

35. Kaewtapee C, Eklund M, Wiltafsky M, Piepho H-P, Mosenthin R, Rosenfelder $P$. Influence of wet heating and autoclaving on chemical composition and standardized ileal crude protein and amino acid digestibility in full-fat soybeans for pigs. J Anim Sci. 2017;95:779-88. https://doi.org/10.2527/jas.2 016.0932.

36. Camarinha-Silva A, Jáuregui $R$, Chaves-Moreno D, Oxley APA, Schaumburg F, Becker $\mathrm{K}$, et al. Comparing the anterior nare bacterial community of two discrete human populations using Illumina amplicon sequencing. Environ Microbiol. 2014;16:2939-52. https://doi.org/10.1111/1462-2920.12362.

37. Kozich JJ, Westcott SL, Baxter NT, Highlander SK, Schloss PD. Development of a dual-index sequencing strategy and curation pipeline for analyzing amplicon sequence data on the MiSeq Illumina sequencing platform. Appl Environ Microbiol. 2013;79:5112-20. https://doi.org/10.1128/AEM.01043-13.

38. Edgar RC, Haas BJ, Clemente JC, Quince C, Knight R. UCHIME improves sensitivity and speed of chimera detection. Bioinformatics. 2011;27:2194200. https://doi.org/10.1093/bioinformatics/btr381.

39. Wang Q, Garrity GM, Tiedje JM, Cole JR. Naive Bayesian classifier for rapid assignment of rRNA sequences into the new bacterial taxonomy. Appl Environ Microbiol. 2007;73:5261-7. https://doi.org/10.1128/AEM.00062-07.

40. Wemheuer F, Taylor JA, Daniel R, Johnston E, Meinicke P, Thomas T, Wemheuer B. Tax4Fun2. A R-based tool for the rapid prediction of habitatspecific functional profiles and functional redundancy based on 165 rRNA gene marker gene sequences; 2018.

41. Yilmaz P, Parfrey LW, Yarza P, Gerken J, Pruesse E, Quast C, et al. The SILVA and "all-species living tree project (LTP)" taxonomic frameworks. Nucleic Acids Res. 2014;42:D643-8. https://doi.org/10.1093/nar/gkt1209.

42. Kanehisa M, Sato Y, Kawashima M, Furumichi M, Tanabe M. KEGG as a reference resource for gene and protein annotation. Nucleic Acids Res. 2016;44:D457-62. https://doi.org/10.1093/nar/gkv1070.

43. McDonald D, Clemente JC, Kuczynski J, Rideout JR, Stombaugh J, Wendel D, et al. The biological observation matrix (BIOM) format or how I learned to stop worrying and love the ome-ome. Gigascience. 2012;1:7. https://doi. org/10.1186/2047-217X-1-7.

44. Verband Deutscher Landwirtschaftlicher Untersuchungs- und Forschungsanstalten. Handbuch der Landwirtschaftlichen Versuchs- und 
Untersuchungsmethodik (VDLUFA-Methodenbuch), Vol. III. Die chemische Untersuchung von Futtermitteln. Darmstadt, Germany: VDLUFA-Verlag; 2007

45. Zeller E, Schollenberger M, Kühn I, Rodehutscord M. Hydrolysis of phytate and formation of inositol phosphate isomers without or with supplemented phytases in different segments of the digestive tract of broilers. J Nutr Sci. 2015;4:e1. https://doi.org/10.1017/jns.2014.62.

46. Sommerfeld V, Künzel S, Schollenberger M, Kühn I, Rodehutscord M. Influence of phytase or myo-inositol supplements on performance and phytate degradation products in the crop, ileum, and blood of broiler chickens. Poult Sci. 2018;97:920-9. https://doi.org/10.3382/ps/pex390.

47. ISO EN 30024. Animal feeding stuffs - Determination of phytase activity. 2009. https://www.iso.org/standard/45787.html. Accessed 06/2020.

48. Siegert W, Hofmann P, Rodehutscord M. Effect of low-temperature drying on the nitrogenous compounds and inositol phosphates in broiler chicken and cecectomized laying hen excreta. Anim Sci J. 2021;92:e13484. https:// doi.org/10.1111/asj.13484.

49. Grubješić G, Titze N, Krieg J, Rodehutscord M. Determination of in situ ruminal crude protein and starch degradation values of compound feeds from single feeds. Arch Anim Nutr. 2019;73:414-29. https://doi.org/10.1080/1 745039X.2019.1641377.

50. Siegert W, Ganzer C, Kluth H, Rodehutscord M. Effect of particle size distribution of maize and soybean meal on the precaecal amino acid digestibility in broiler chickens. Br Poult Sci. 2018;59:68-75. https://doi.org/1 0.1080/00071668.2017.1380295

51. Borda-Molina D, Zuber T, Siegert W. Camarinha da Silva a, Feuerstein D, Rodehutscord M. effects of protease and phytase supplements on small intestinal microbiota and amino acid digestibility in broiler chickens. Poult Sci. 2019;98:2906-18. https://doi.org/10.3382/ps/pez038.

52. Clarke KR, Warwick RM. Change in marine communities: an approach to statistical analyses and interpretation. 2nd ed. PRIMER-E: Plymouth; 2001

\section{Publisher's Note}

Springer Nature remains neutral with regard to jurisdictional claims in published maps and institutional affiliations.

Ready to submit your research? Choose BMC and benefit from:

- fast, convenient online submission

- thorough peer review by experienced researchers in your field

- rapid publication on acceptance

- support for research data, including large and complex data types

- gold Open Access which fosters wider collaboration and increased citations

- maximum visibility for your research: over $100 \mathrm{M}$ website views per year

At $\mathrm{BMC}$, research is always in progress.

Learn more biomedcentral.com/submissions 